\title{
Evolution and skeletal characteristics of European owls
}

\author{
Jenő (Eugen) KESSLER
}

Received: August 23, 2017 -Accepted: October 06, 2017

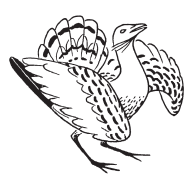

Kessler J. (E.) 2017. Evolution and skeletal characteristics of European owls. - Ornis Hungarica 25(2): 65-103. DOI: 10.1515/orhu-2017-0016

Abstract Owls represent typical nocturnal avian predators. They are known since the beginning of the Tertiary. Thirteen species live in Europe, but the number of extinct fossil species is only slightly above twice that number. The present genera appeared in the Neogene period. They also have a major significance regarding palaeoecology, since most of the fossilized remains of small-medium sized vertebrates are available from owl pellets. The author wishes to describe the occurrence and evolution of owls in Europe from the Cretaceous to current times, as well as to provide an osteological guide of recent species. The text is supplemented by 16 plates, 4 size charts, and extensive bibliography.

Keywords: Europe, owl, evolution, palaeoecology, osteology

Összefoglalás A baglyok a madárvilág jellegzetes éjjeli ragadozóit képviselik. A harmadidőszak elejétől már ismertek. Európában 13 fajuk él, de a kihalt fosszilis fajaik száma is alig éri el ennek a kétszeresét. A mai nemzetségek a Neogénben jelentek meg. Jelentőségük paleoökológialag igen nagy, hiszen a kis-közép és kistermetủ szárazföldi gerincesek fosszilis maradványainak nagy része az ő köpetelő tevékenységüknek köszönhető. A jelen tanulmányban a szerző a baglyok európai jelenlétét és evolúcióját mutatja be a Krétától napjainkig, valamint a recens fajok csonttani határozóját is megadja. A szöveget 16 táblakép, 4 mérettáblázat és irodalomjegyzék egészíti ki.

Kulcsszavak: Európa, bagoly, evolúció, paleoökológia, csonttan

Department of Paleontology, Eötvös Loránd University, 1117 Budapest, Pázmány Péter sétány 1/c, Hungary, e-mail: kessler_jeno@yahoo.com

\section{Introduction}

The order Strigiformes consists of nocturnal predators, although numerous species (like Snowy Owls and Short-eared Owls) also prey and feed during the day. They are present all across the globe except Antarctica and a number of oceanic islands. They vary in size, and so do their prey (from insects to bigger birds, fawn-sized mammals). Females are typically larger than males. They nest in crevices of rocks, tree burrows, uninhabited nests and buildings, their nestlings remain in the nest. Consumed but undigested body parts (bones, feathers, hair, scales) are disposed of in the form of pellets at their resting place regularly at the same location. True owls, barn owls, and a few extinct species belong to this category. The number of extinct and identified species is more than 200 worldwide.

True owls (Strigidae) incorporate numerous species. Their time of appearance within the fauna is uncertain. Two giant species reported in the 1970's from the Late Cretaceous 
(Maastrichtian stage) of the Hátszegi Basin in Transylvania (Bradycneme draculae Harrison et Walker, 1975, Heptasteornis andrewsi Harrison et Walker, 1975) (Harrison \& Walker 1975) were not accepted and are claimed by most professionals to be Maniraptora dinosaur remains (Feduccia 1999).

Their earliest actual sign comes from the Paleocene of the USA(Ogygopterynx wetmorei Rich et Bohaska, 1976) and the Eocene of Germany and France (Palaeoglaux artophpron Peters, 1992, P. perrierensis Mourer-Chauviré, 1987). We know of the genera Mioglaux from the Miocene of France and the Czech Republic with species M. poirrieri (Milne-Edwards, 1863) and M. deballatrix (Mlíkovský, 1998), as well as Intilula from the Miocene of the Czech Republic and Germany with species I. tinnipara (Mlíkovský, 1998) and I. brevis (Ballmann, 1969).

Recent genera have also been found from the Miocene-Pliocene, for example the genus Strix from the Miocene, with species $S$. dakota (A. H. Miller, 1944) in the USA, $S$ winterhofensis (Ballmann, 1969), S. edwardsi (Ennouchi, 1930) in Germany; the genus Surnia from the Miocene, Pliocene and Pleistocene of the Czech Republic and Hungary with species S. robusta (Jánossy, 1977) and S. capeki (Jánossy, 1972); genus Glaucidium from the Pliocene of Hungary (Beremend, Csarnóta) with G. baranensis (Kessler, 2010); genus Bu$b o$ from the Miocene of Hungary (Csákvár) with species B. florianne (Kretzoi, 1957); genus Asio from the Miocene of Ukraine with A. longaevus (Umans'ka, 1979) (Bochenski 1997, Mlíkovský 2002, Kessler 2013).

Barn owls (Tytonidae) are present in recent fauna with a cosmopolitan species (Tyto alba) and its numerous subspecies worldwide. Their extinct genera are Palaeotyto from the Oligocene of France with species $P$. cadurcensis (Mourer-Chauviré, 1987), and species of the genera Necrobyas and Prosybris: N. harpax (Milne-Edwards, 1892), N. arvernensis (Milne-Edwards, 1863), N. rossignoli (Milne-Edwards, 1892), P. media (Mourer-Chauviré, 1987), $P$. antiqua (Milne-Edwards, 1863); as well as the genus Basityto from the Miocene of Germany with species such as B. rummeli (Mlíkovský, 1998), while extinct species of the recent genus are Tyto sanctialbani (from the Miocene and Pliocene of France, Germany and Italy), T. campiterrae (from the Miocene of Hungary), T. balearica (from the Miocene of Spain), $T$. gigantea (from the Pliocene of Italy) (Brodkorb 1971, Olson 1985, Mourer-Chauviré 1987, Bochenski 1997, Mlíkovský 1998a, 1998b, 2002).

In the extinct Protostrigidae family, Protostrix is represented by species P. lydekkeri (Shufeldt, 1913), P. leptosteus (Marsh, 1871), P. sauriodosis (Wetmore, 1921), P. californiensis (Howard, 1965) and genus Eostrix with species E. martinelli (Martin et Black, 1972), E. mimica (Wetmore, 1938) and E. vincenti (Harrison, 1980) from the Eocene of the USA, and Oligostrix rupelensis (Fischer, 1982) from the Oligocene of Germany (Brodkorb 1971, Olson 1985, Mlíkovský 2002).

The extinct Sophiornithidae family is represented by a number of extinct genera and species among the fossil record. Earliest known examples are Berruornis orbisantaqui (Mourer-Chauviré, 1994) from the Paleocene of France, and from the Eocene by Sophironis quercynus (Mourer-Chauviré, 1987) and Palaeobyas cracrafti (Mourer-Chauviré, 1987) (Brodkorb 1971, Olson 1985, Mourer-Chauviré 1987, Bochenski 1997, Mlíkovský 2002).

It is worth noting that there is quite a number of overlaps, renaming and synonymizing when classifying extinct genera and species to the above-mentioned families. 
Newer systematic paradigms suppose kinship between owls and Caprimulgiformes (Jarvis et al. 2014).

\section{Systematics}

Thirteen species are known in the recent avian fauna of Europe. They are all present in the Carpathian Basin as well, but the Snowy Owl (Nyctea scandiaca), the Great Grey Owl (Strix nebulosa) and the Northern Hawk-owl (Surnia ulula) only as occasional or winter guests.

The occurrence of recent genera and species at sites of the Carpathian Basin and Europe, and signs of fossilized species from the Carpathian Basin are as follows:

Abbreviations: Q1-Q2 - Lower Pleistocene; Q3 (Q3/I-Q3/II) - Middle Pleistocene; Q4/I - Upper Pleistocene; Q4/II - Holocene; $\dagger$ - extinct/fossil species.

Ord. Strigiformes (Wagler)

Fam. Tytonidae Ridgway, 1914

- Tyto alba (Scopoli, 1769)

Known from the Carpathian Basin Q1: of Betfia 2 (Romania) (Kormos 1913, Čapek 1917, Lambrecht 1933, Kessler 1975, Jánossy 1977, Gál 2002); Q3/II: of Vindija (Croatia) (M. Malez 1961, V. Malez 1973, 1988, 1991, V. Malez \& Rukavina 1975), as well as the Q3: of France, Greece, Malta; Q4/I-II: of Bosnia Herzegovina, Croatia, Czech Republic, France, Greece, Ireland, Italy, Portugal, Spain, Switzerland, United Kingdom (Tyrberg 1998).

- Tyto sp. indet.

Known from the Carpathian Basin Q1: of Beremend 17 (Hungary) (Kessler 2010), as well as the Q3: Italy (Tyrberg 1998).

- Tyto † sanctialbani (Lydekker, 1893)

Known from the Upper Miocene (MN 10) of the Carpathian Basin: Gyepüfüzes (Kohfidisch) (Austria), (Mlíkovský 2002).

- Tyto † campiterrae (Jánossy, 1991)

Known from the Upper Miocene (MN 13) of the Carpathian Basin: Polgárdi 4, 5 (Hungary) (Jánossy 1991, 1995, Kessler 2010).

- Tyto † melitensis (Lydekker, 1891)

Known in the European Quaternary from Q4/II: of Malta (Tyrberg 1998).

- Tyto $\dagger$ balearica Mourer-Chauviré, Alcover (Moya et Pons, 1980)

Known in the European Neogene and Quaternary from MN 15: of France; Q1: of Spain (Tyrberg 1998).

- Prosybris antiqua (Milne-Edwards, 1863)

Known from the Lower Miocene (MN 3-4) of the Carpathian Basin: Limberg (Austria) (Mlikovskỳ 1998).

Fam. Strigidae Vigors

- Otus scops (Linnaeus, 1758)

Known from the Carpathian Basin Q1: of Betfia 2 (Romania) (Kormos 1913, Čapek 1917, Lambrecht 1933); Q3/I: of Betfia 7/4 (Romania) (Kessler 1975, Jánossy 1977, Gál 2002); Q3/II: of Vindija (Croatia) (M. Malez 1961, V. Malez 1973, 1988, 1991, V. Malez \& 
Rukavina 1975); Q4/I: of Pilisszántói I. Niche (Hungary) (Lambrecht 1915, 1933, Jánossy 1977, 1979, 1986), as well as the Q1: of Spain; Q3: of Azerbaijan, Italy; Q4/I-II: of Croatia, Czech Republic, France, Greece, Italy, Moldova, Portugal, Spain, Ukraine, United Kingdom (Tyrberg 1998).

- Bubo bubo (Linnaeus, 1758)

Known from the Carpathian Basin Q1: of Betfia 2 (Romania) (Kormos 1913, Čapek 1917, Lambrecht 1933, Kessler 1975, Jánossy 1977, Gál 2002); Q2: of Nagyharsányhegy 1-4 (Hungary) (Lambrecht 1916, 1933); Q3/I: of Vértesszőlös 2 (Hungary) (Jánossy 1990); Q3/ II: of Vindija (Croatia) (M. Malez 1961, V. Malez 1973, 1988, 1991, V. Malez \& Rukavina 1975); Q4/I: of Krapina (Croatia); Buják, Hámor-Herman Ottó Cave, Tokod-Nagyberek (all in Hungary); Szegyestel-Tibocoaia Cave (Sighiștel) (Romania) (Lambrecht 1912, 1915, V. Malez 1973, 1984, Jánossy 1978, 1979, Kessler 1982, 1985, M. Malez \& V. Malez 1988, Gál 2002); Q4/II: of Teufelslucken (Austria); Csákvár-Esterházy Cave, Polgár-Csőszhalom, Tiszapolgár-Csőszhalom, Visegrád-Vár (all in Hungary); Körösrévi Caves (Vadu Crișului), Kazánszoros-Töröklik Cave (Cazanele Mari Defile), Szegyestel-Tibocoaia Cave (Sighiștel Defile) (all in Romania) (Bökönyi \& Jánossy 1965, Soergel 1966, Kessler 1974a, 1982, Fischer \& Stephan 1977, Jánossy 1979, 1985, Gál 2004, 2005, 2007b), as well as the Q1-2: of Spain; Q3: of Azerbaijan, France, Germany, United Kingdom; Q4/I-II: of Austria, Belgium, Belorussia, Bulgaria, Czech Republic, France, Georgia, Germany, Italy, Poland, Portugal, Romania, Russia, Spain, Serbia, Ukraine, United Kingdom (Tyrberg 1998). - Bubo/Nyctea sp.

Known in the European Quaternary from Q3: of France; Q4/I: of Austria (Tyrberg 1998). - Bubo bubo $\dagger$ davidi (Mourer-Chauviré, 1975)

Known in the European Quaternary from Q3: of France; Q4/I: of Spain (Tyrberg 1998). - Bubo? †florianae (Kretzoi, 1957)

Known from the Upper Miocene (MN 11) of the Carpathian Basin: Csákvár (Hungary) (Kretzoi 1957).

- Bubo † binagedensis (Burchak-Abramovich, 1965)

Known in the European Quaternary from Q3: of Azerbaijan (Tyrberg 1998).

- Bubo † insularis (Mourer-Chauviré et Weesie, 1986)

Known in the European Quaternary from Q4/I: of France, Italy (Tyrberg 1998).

- Bubo sp. foss. indet.

Known from the Carpathian Basin MN 15: of Csarnóta 2 (Hungary) (Kretzoi 1961-62, Jánossy 1977); MN 16: of Osztramos 7, Villány 3 (all in Hungary) (Jánossy 1973, 1977, Kessler 2010).

- Surnia ulula (Linnaeus, 1758)

Known from the Carpathian Basin Q4/I: of Luegloch (Austria); Budapest-Remetehegyi Niche, Felsőtárkány-Peskő Cave, Gencsapáti, Hámor-Puskaporos Niche, Pilisszántói I. Niche, Répáshuta-Balla Cave, Szilvásvárad-Istállóskői Cave, Varbó-Lambrecht Kálmán Cave (all in Hungary); Detrekőszentmiklós-Pálffy Cave (Dzereva Skála) (Slovakia) (Lambrecht 1912, 1913, 1916, 1933, Jánossy 1952, 1954, 1955, 1977, 1979, 1986, Mottl 1953), as well as the Q3: of Germany, Italy; Q4/I: of Austria, France, Germany, Italy, Poland, Russia, Switzerland, Ukraine, United Kingdom (Tyrberg 1998). 
- Surnia † robusta (Jánossy, 1977)

Known from the Upper Miocene (MN 13) of the Carpathian Basin: Polgárdi 4, 5 (Hungary) (Kessler 2010); MN 16: of Osztramos 7, Beremend 4, Villány 3 (all in Hungary) (Jánossy 1977); Q1-2: of Nagyharsányhegy 1-4, Somssich Hill 2 (all in Hungary) (Jánossy 1977, 1982, 1983, 1986).

- Surnia † capeki Jánossy, 1978

Known in the European Quaternary from Q3: of the Czech Republic (Jánossy 1972).

- Glaucidium passerinum (Linnaeus, 1758)

Known from the Carpathian Basin Q1: of Németóvár (Deutsch Altenburg) (Austria); Betfia 2, 9 (Romania) (Kormos 1913, Čapek 1917, Lambrecht 1933, Jánossy 1977, 1979, 1981, Gál 2002); Q3/I: of Hundsheim (Austria) (Jánossy 1974, Mlikovskỳ 2002); Q4/I: of Budapest-Remetehegyi Niche, Hámor-Hermann Ottó Cave (all in Hungary) (Lambrecht 1912, 1915, 1933, Jánossy 1977, 1979, 1986), as well as the Q1-2: of Greece, Poland; Q3: of the Czech Republic, Germany, Turkey; Q4/I-II: of the Czech Republic, France, Germany, Poland (Tyrberg 1998).

- Glaucidium † baranensis Kessler, 2010

Known from the Lower Pliocene (MN 15) of the Carpathian Basin: Csarnóta 2, Beremend 26 (all in Hungary) (Kessler 2010, 2013).

- Athene noctua (Scopoli, 1769)

Known from the Carpathian Basin Q4/I: of Pilisszántói I. Niche (Hungary); Barcarozsnyó-Gura Cheii Cave (Râșnov) (Romania) (Lambrecht 1915, 1933, Jánossy 1977, 1979, 1986, Gál 1998, 2002); Q4/II: of Balatonkeresztúr-Réti-dülő, Pilismarót-Malompatak (Hungary); Révtizfalusi Cave (Zece Hotare), Szegyestel-Drăcoaia Cave (Sighiștel Defile) (Romania) (Kessler 1982, Jánossy 1985, Gál 2007a, 2007b), as well as the Q1-2: of France, Ukraine; Q3: of Azerbaijan, Czechia, France, Greece, Italy, Ukraine; Q4/I-II: of Croatia, Czech Republic, France, Grece, Italy, Moldova, Portugal, Spain, Ukraine, United Kingdom (Tyrberg 1998).

- Athene noctua † veta (Jánossy, 1992) / A. veta (Jánossy, 1974)

Known from the Upper Miocene (MN 13) of the Carpathian Basin; Polgárdi 4 (Hungary) (Kessler 2010); MN 15: of Csarnóta 2, Beremend 26 (all in Hungary) (Kessler 2010); MN 16: of Osztramos 7 (Hungary) (Jánossy 1979); Q1: Beremend 16, 17 (Hungary) (Jánossy 1991,1992, 1996); Q2: of Somssich Hill 2 (Hungary) (Jánossy 1982, 1983, 1986), as well as MN 16: of Poland; Q1-2: of Austria, Spain (Tyrberg 1998).

- Athene noctua † lunellensis Mourer-Chauviré, 1975

Known in the European Quaternary from Q1-2: France; Q3: of France (Tyrberg 1998).

- Athene $\dagger$ cretensis Weesie, 1982

Known in the European Quaternary from Q4/I-II: of Greece (Tyrberg 1998).

- Athene sp.

Known in the European Quaternary from Q3: of Italy; Q4/I: of Spain (Tyrberg 1998).

- Athene sp. foss. indet.

Known from the Upper Miocene (MN 9) of the Carpathian Basin: Rudabánya (Jánossy 1994).

- Strix aluco (Linnaeus, 1758) 
Known from the Carpathian Basin Q4/I: of Krapina, Velika Pecina (all in Croatia); Esküllő-Igric Cave (Igriţa-Aștileu), Nándor-Nándori Cave (Curata-Nandru), Szegyestel-Tibocoaia Cave (Sighiștel Defile) (all in Romania) (Jánossy 1965, V. Malez 1973, 1975, 1984, 1988, Fischer \& Stephan 1977, Kessler 1982, 1985, Jurcsák \& Kessler 1988, M. Malez \& V. Malez 1988, Gál 2002, 2003); Q4/II: of Bodajk-Rigólyuk, Budapest-Aquincum, Ecsegfalva 23 sz., Endrőd 119, Jósvafő-Musztáng-Cave, Legény Cave, Miskolc-Felsőforrás, Visegrád Castle (all in Hungary); Felsőlubkó (Gornea), Körösbánlaki Cave (Bălnaca), Parác (Parţa), Remetelórév-Bólyikő Cave (Piatra Boiului-Lorău), Kőrösrévi Caves (Vadu Crișului Defile), Révtizfalusi Cave (Zece Hotare), Szegyestel-Drăcoiaia Cave (Sighiștel Defile), Szegyestelvölgyi Caves (Sighiștel Defile), Vaskóh (Vaṣcäu), Vársonkolyosi Caves (Şuncuiuṣ Defile) (all in Romania); Vlassac (Serbia) (Bökönyi \& Jánossy 1965, Jánossy 1977, 1985, Kessler 1982, 1985, 2010, Kordos 1984, Kessler \& Gál 1997, Gál 2004, 2007b, Pike-Tay et al. 2004), as well as the Q1-2: of Greece; Q3: Czech Republic, France, Georgia, Germany, Russia, Spain; Q4/I-II: Austria, Bosnia Herzegovina, Bulgaria, Croatia, Czech Republic, France, Germany, Italy, Moldova, Poland, Russia, Spain, Switzerland, Ukraine, United Kingdom (Tyrberg 1998).

- Strix nebulosa (Forster, 1772)

Known from the Carpathian Basin Q4/I: of Nándori Cave (Curata-Nandru) (Romania) (Jánossy 1965), as well as the Q3: of the Czech Republic; Q4/I-II: of Austria, Italy, Russia (Tyrberg 1998).

- Strix uralensis (Pallas, 1771)

Known from the Carpathian Basin Q4/I: of Budapest-Remetehegyi Niche (Hungary); Detrekőszentmiklós-Pálffy (Dzereva Skála) (Slovakia) (Lambrecht 1913, 1933, Jánossy 1979, 1986); Q4/II: of Aggtelek Cave, Pilismarót-Malompatak (all in Hungary) (Jánossy 1977, 1985); Körösrévi Caves (Vadu Crișului Defile) (Romania) (Kessler 1982), as well as the Q4/I-II: of the Czech Republic, Italy, Poland (Tyrberg 1998).

- Strix $\uparrow$ intermedia (Jánossy, 1972)

Known from the Carpathian Basin MN 15: of Beremend 26 (Hungary) (Kessler 2010); MN 16: of Villány 3 (Hungary) (Kessler 2010); Q1: of Beremend 16, 17 (Hungary) (Jánossy 1992, 1996); Q3/I: of Hundsheim (Austria) (Jánossy 1974); Tarkő 10, 11, 12, 13 (Hungary); Gombaszög (Gombasek) (Slovakia); (Jánossy 1974, 1977, 1979; Kessler 2010), as well as the Q3: of Czech Republic, France; Q4/I: of Spain (Tyrberg 1998).

- Strix sp.

Known in the European Quaternary from Q4/I-II: of France, Germany, Italy, Russia, Spain (Tyrberg 1998).

- Aegolius funereus (Linnaeus, 1758)

Known from the Carpathian Basin Q1: of Betfia 9 (Romania) (Gál 2002); Q3/I: of Tarkö/3, 12 (Hungary); Betfia 7/4 (Romania) (Kessler 1975, Jánossy 1979, Gál 2002); Q4/I: Budapest-Remetehegyi Niche, Cserépfalu-Subalyuk Cave, Hámor-Puskaporos Niche, Hámor-Herman Ottó Cave, Pilisszántói I. Niche, Szilvásvárad-Istállóskői Cave, Tatabánya-Szelim Cave (all in Hungary); Barcarozsnyó-Gura Cheii Cave (Râșnov) (Romania) (Lambrecht 1912, 1915, 1916, 1933, Jánossy 1952, 1955, 1977, 1979, 1986, Gál 1998, 2002); Q4/II: of Teufelslucken (Austria) (Soergel 1966), as well as the Q3: of Azerbaijan, 
Czech Republic, France, Germany; Q4/I-II: of the Czech Republic, France, Greece, Germany, Italy, Poland, Russia, Ukraine, United Kingdom (Tyrberg 1998).

- ? Aegolius sp. foss. indet.

Known from the Carpathian Basin MN 15: of Csarnóta (Hungary) (Jánossy 1977, 1979, 1980); MN 16: of Villány 3 (Hungary) (Jánossy 1977, 1979, 1980).

- Asio flammeus (Pontoppidan, 1863)

Known from the Carpathian Basin Q1: of Osztramos 8 (Hungary) (Jánossy \& Kordos 1976); Betfia 2 (Romania) (Kormos 1913, Čapek 1917, Lambrecht 1933, Kessler 1975, Jánossy 1977, Gál 2002); Q3/I: of Tarkő 2, Vértesszőlős 2 (all in Hungary) (Jánossy 1977, 1979); Q3/II: of Vindija (M. Malez 1961, V. Malez 1973, 1988, 1991, V. Malez \& Rukavina 1975); Uppony 3 (Hungary) (Jánossy 1977, 1979); Q4/I: of Merkenstein (Austria); Bajót-HómanCave, Bajót-Jankovich Cave, Budapest-Remetehegyi Niche, Hámor-Puskaporos Niche, Hámor-Herman Ottó Cave, Pilisszántói I. Niche, Répáshuta-Balla Cave, Répáshuta-Ballavölgyi Cave, Szilvásvárad-Istállóskői Cave, Tatabánya-Szelim Cave, Tokod-Nagyberek (all in Hungary); Körösmart (Râpa), Nándor-Nándori Cave (Curata-Nandru), Szegyestel-Tibocoaia Cave (Sighiștel Defile) (all in Romania); Detrekőszentmiklós-Pálffy Cave (Dzereva Skála), Novi I, III (all in Slovakia) (Nehring 1880, Róth 1881, Lambrecht 1912, 1915, 1916, 1933, Mottl 1941, Wettstein \& Mülhoffer 1938, Jánossy 1952, 1955, 1965, 1977, 1979a, 1986, Jánossy in Hamar \& Csák 1969, Kessler 1974b, 1982, 1985, Fischer \& Stephan 1977, Jurcsák \& Kessler 1988, Gál 2002, 2003); Q4/II: of Grosse Offenbergerhöhle, Teufelslucken (all in Austria); Bégakalodva (Cladova), Parác (Parţa) (all in Romania) (Soergel 1966, Bocheński \& Tomek 1994, Kessler \& Gál 1997, Gál 2004), as well as the Q3: of Azerbaijan, Czechia, France, Russia, Ukraine, United Kingdom; Q4/I-II: of Belgium, Bosnia Herzegovina, Czech Republic, France, Greece, Germany, Luxemburg, Moldova, Poland, Portugal, Russia, Spain, Ukraine, United Kingdom (Tyrberg 1998).

- Asio otus (Linnaeus, 1758)

Known from the Carpathian Basin MN 16: of Villány 3 (Hungary); Betfia 13 (Romania) (Kessler 1975, 2010, Gál 2002); Q1: of Betfia 2, 9 (Romania) (Kormos 1913, Čapek 1917, Lambrecht 1933, Kessler 1975, Jánossy 1977, Gál 2002); Q3/II: of Vindija (Croatia) (M. Malez 1961, V. Malez 1973, 1988, 1991, V. Malez \& Rukavina 1979); Q4/I: of Velika Pecina (Croatia); Budapest-Remetehegyi Niche (Lambrtecht 1915), Felsőtárkány-Peskő Cave (Lambrecht 1912, 1933, Jánossy 1977, 1979, 1986), Pilisszántói I. Niche (all in Hungary); Szegyestel-Tibocoaia Cave (Sighiștel Defile) (Romania) (Lambrecht 1915, 1933, V. Malez 1975, 1984, 1988, Jánossy 1977, 1979, 1986, Kessler 1982, 1985, Gál 2002); Q4/II: of Teufelslucken (Austria); Bodajk-Rigólyuk (Hungary); Remetelórév-Bólyikői Cave (Piatra Boiului-Lorău), Körösrévi Caves (Vadu Crișului Defile), Szkerisoara-Sasok Cave (Peștera Vulturilor-Scăriṣoara) (all in Romania) (Soergel 1966, Kessler 1982, Kordos 1984, Jurcsák \& Kessler 1986, 1988), as well as the Q3: of Azerbaijan, France, Germany, Italy; Q4/I-II: of Austria, Belgium, Bosnia Herzegovina, Croatia, Czech Republic, France, Germany, Luxemburg, Poland, Romania, Serbia, Spain, Ukraine, United Kingdom (Tyrberg 1998).

- Asio sp. indet.

Known from the Carpathian Basin Q1: of Beremend 17 (Hungary) (Jánossy 1992, 1996), as well as the Q4/I-II: of Belgium, France, Germany, Moldova, Russia, Ukraine (Tyrberg 1998). 
- Nyctea scandiaca (Linnaeus, 1758)

Known from the Carpathian Basin Q3/II: of Vindija (Croatia) (M. Malez 1961, V. Malez 1973, 1988, 1991, M. Malez \& Rukavina 1979); Q4/I: of Merkenstein (Austria); Budapest-Remetehegyi Niche, Bivak Cave, Buják, Hámor-Puskaporos Niche, Varbó-Lambrecht Kálmán Cave (all in Hungary); Detrekőszentmiklós-Pálffy Cave (Dzereva Skála), Novi I, III (all in Slovakia) (Nehring 1880, Róth 1881, Lambrecht 1912, 1916, 1933, Wettstein \& Mülhofer 1938, Jánossy 1977, 1979, 1986); Q4/II: of Grosse Offenbergerhöhle, Hohlensteinhöhle (all in Austria); Csákvár-Esterházy Cave (Hungary); Kisderzsida (Derșida Mică) (Romania) (Kretzoi 1957, Bocheński \& Tomek 1994, Bindea 2008), as well as the Q1-2: of France; Q3: of Azerbaijan, France, Germany, United Kingdom; Q4/I-II: of Austria, Belgium, Croatia, Czech Republic, France, Germany, Italy, Netherlands, Poland, Russia, Spain, Switzerland, Ukraine, United Kingdom (Tyrberg 1998).

- Nyctea scandiaca † gallica Mourer-Chauviré, 1975

Known in the European Quaternary from Q3: of France; Q4/I: of France (Tyrberg 1998).

- Nyctea sp.

Known from the Carpathian Basin Q4/I: of Velika Pecina (Croatia); Szilvásvárad-Istállóskői Cave (Hungary) (Lambrecht 1912, 1933, Jánossy 1952, 1955, 1977, 1979, 1986, V. Malez 1975, 1984, 1988), as well as the Q3: of France (Tyrberg 1998).

- †Intulula (Mlikovskỳ, 1998)

- †Intulula brevis (Ballmann, 1969) / Strix aff. brevis (Ballmann, 1969)

Known from the Upper Miocene (MN 9) of the Carpathian Basin: Rudabánya (Hungary) (Jánossy 1993).

- Strigidae gen. et sp. foss. indet.

Known from the Middle Miocene (MN 7/8) of the Carpathian Basin: Felsőtárkány-Felnémet 2/3 (Hungary) (Kessler \& Hír 2012).

\section{Palaeoecological Conclusions}

The palaeoecological significance of owls is major, primarily of species living, digesting and nesting at locations where the bones in their pellets are able to fossilize and become preserved due to advantageous taphonomic conditions. Such locations are caves, crevices of rocks or cliffs of karst plateaus. Since owls usually dispose of pellets at the same location, they can accumulate, sometimes during a number of generations, forming bone breccias in sediments. The layers of these form the basis of the fine-layer segmentation of the Neogene, but mainly the Quaternary.

\section{Osteological characteristics of owls in Europe}

Skeletal parts of owls are relatively easy to identify. On the one hand, females are typically bigger than males (thus the sizes given in the size chart are for information purposes only), and on the other, they are usually robust, apart from the Barn Owl. These are the mandible, the coracoid of the pectoral girdle, the scapula, and bones of the upper and lower limbs (apart from the fibula and certain phalanges). The skull, the sternum and the synsacrum are 
also typical, although these usually did not preserve, unlike bones of the pectoral girdle and the limbs.

\section{Method}

For every discussed skeletal part, the anatomical terminology (after: Lambrecht 1933, Ballmann 1966, 1973, 1976, Baumel et al. 1979, Langer 1980, Gilbert et al. 1981, Jánossy 1985, Kessler 2013) and method of measurement (von den Driesch 1976, Langer 1980, Gál 2002, Kessler 2013) of the bone in question is given, illustrated by the appropriate bone of the Eurasian Eagle-owl (Bubo bubo). Arrows indicate the coded characteristics (Plate 1-2) and the method of measurement (Plate 3).

According to skeletal parts, their characteristics are the following:

\section{Coracoideum (Plate 4):}

Generally, relatively short and stout, except for the barn owl. Under the straight and clublike processus acrocoracoidalis (a) the body is stout, and has a triangle-shaped pointed, but cranially curved processus procoracoidalis (e) extending from it, with a well-defined foramen procoracoideus (b) located on it. The sternal end is asymmetrically triangle-shaped.

- a: processus acrocoracoidalis:

- cublike: Aegolius, Asio flammeus, A. otus, Athene, Bubo, Nyctea, Surnia;

- medially dented: Otus, Strix aluco, S. uralensis, Tyto;

- b: foramen procoracoideus:

- small: Aegolius, Asio otus, Surnia;

- big and round: Athene, Strix uralensis;

- big and oval: Aegolius, Asio flammeus, Bubo, Nytea, Otus, Strix aluco;

- c: angulus medialis:

- long and pointed: Asio flammeus;

- long and blunt: Asio otus, Strix uralensis, Tyto;

- short and pointed: Otus, Nyctea, Strix aluco, Surnia;

- short and blunt: Aegolius, Athene, Bubo;

- d: processus lateralis:

- rounded: Aegolius, Otus, Surnia;

- cut-off and narrow: Asio flammeus, A. otus, Bubo, Nyctea, Strix aluco, S. uralensis;

- cut-off and wide: Tyto

\section{Scapula (Plate 5)}

It shows few easy-to-define characteristics.

- a: acromion:

- rounded: Aegolius, Athene, Glaucidium, Nyctea, Otus, Tyto;

- asymmetrical: Asio flammeus, A. otus,, Bubo, Strix aluco, S. uralensis, Surnia;

- b: processus articularis humeralis:

- rounded: Aegolius, Athene, Glaucidium; 
- cut-off: Asio otus, Otus, Surnia;

- cone shaped: Nyctea;

- asymmetrical: Asio flammeus, Bubo, Strix aluco, S. uralensis, Tyto;

- c: corpus scapulae:

- straight: Glaucidium, Otus, Surnia;

- significantly curved: Aegolius, Asio flammeus, Bubo, Nyctea, Strix aluco, S. uralensis, Tyto;

- curved at the end: Asio otus, Athene

\section{Humerus (Plate 7)}

As with other birds, it is one of the most well-diagnosable skeletal parts of owls, furthermore, this applies to both epiphyses on their own. On the proximal epiphysis, the caput humeri (f) is definitely cambering, crista deltopectoralis $(\mathrm{g})$ is arched, tuberculum dorsale $(\mathrm{h})$ and tuberculum ventrale (i) are well-defined, fossa pneumotricipitalis (j) is round, deep and there is only one, distally; impressio coracobrachialis $(\mathrm{k})$ is wide and well-defined, however, sulcus transversus (1) is poorly developed.

The distal epiphysis is wide, the fossa musculi brachialis (m) well-developed and shaped like an equilateral triangle. The condylus ventralis (n) and the condylus dorsalis (o) are well-developed.

- a: the edge of the crista biccipitalis on the caudalis side (crus ventrale fossae):

- slightly curved: Asio otus, Otus, Strix uralensis, Tyto;

- significantly curved, protuberant: Aegolius, Athene;

- cut-off: Asio flammeus, Bubo, Nyctea, Strix aluco;

- b: crus dorsale fossae:

- sharply protruding: Aegolius, Athene, Nyctea, Otus, Strix aluco, Tyto;

- poorly developed: Asio flammeus, A. otus, Bubo, Strix uralensis;

- c: corpus humeri:

- straight: Asio flammeus, A. otus, Bubo;

- slightly curved: Athene, Nyctea, Otusd, Strix aluco, S. uralensis;

- significantly curved: Aegolius;

- d: epicondylus ventralis:

- protrusive: Aegolius, Asio flammeus, Athene, Otus, Surnia;

- rounded: Asio otus, Bubo, Nyctea, Strix aluco, S. uralensis, Tyto;

- e: processus supracondylaris dorsalis:

- well developed: Aegolius, Athene, Bubo, Otus, Strix aluco, S. uralensis, Surnia;

- poorly developed: Asio flammeus, A. otus, Nyctea, Tyto

\section{Ulna (Plate 8-9)}

It is not an easy-to-define skeletal part. The proximal epiphysis, for example, practically has almost no characteristics that would help reach a certain conclusion regarding species. The olecranon (b) has a blunt cone shape, cotyla ventralis (apophysis glenoidalis interna) (c) is round, while the cotyla dorsalis (apophysis glenoidalis externa) (a) is straightly protruding. The impressio brachialis (d) is well-developed and deep. The corpus ulnae (e) is slightly curved, the papillae remigialis (dorsalis and ventralis) (f) are 
weakly defined. The condylus dorsalis ulnaris (g) on the distal epiphysis is semi-circular, the condylus ventralis ulnaris (h) is a blunt cone, the tuberculum carpale (i) is a pointed cone, which is typical to the genera, but does not provide sufficient points for identification to the species level.

- a: apophysis glenoidalis externa:

- is a pointed cone: Otus;

- blunt cone: Aegolius, Asio otus, A. flammeus, Athene, Bubo, Nyctea, Surnia;

- rounded: Strix aluco, S. uralensis;

- cut-off: Tyto

\section{Radius (Plate 10)}

A skeletal part is less suitable for identification. On the caput radii forming the proximal epiphysis, only the tuberculum bicipitale (a) shows distinctive characteristics, the form of corpus radii (b) is slightly different, while on the distal epiphysis the tuberculum aponeurosis ventrale (c) and the tuberculum aponeurosis dorsale (d) can be diagnosed.

- a: tuberculum bicipitale:

- protrusive: Bubo, Otus, Strix aluco, S. uralensis, Surnia;

- underdeveloped: Aegolius, Asio flammeus, A. otus, Athene, Nyctea, Tyto;

- b: corpus radii:

- slightly curved: Bubo, Strix aluco;

- shaped like an elongated S: Aegolius, Asioflammeus, A. otus, Athene, Nyctea, Otus, Strix uralensis, Surnia, Tyto;

- c: tuberculum aponeurosis ventrale:

- pointening: Asio flammeus, Bubo, Nyczea, Otus, Strix aluco, Strix uralensis, Surnia;

- rounded: Aegolius, Asio otus, Athene, Tyto;

- d: tuberculum aponeurosis dorsale:

- pointening: Asio otus, Athene, Bubo, Nyctea, Strix aluco, S. uralensis, Surnia, Tyto;

- rounded: Aegolius, Asio flammeus, Otus

\section{Carpometacarpus (Plate 11)}

The carpometacarpus of owls is relatively robust. The processus intermetacarpale is missing.

- a: processus extensorius:

- straight blunt cone: Otus;

- asymmetrical oblique blunt cone: Aegolius, Asio flammeus, A. otus;

- straight, with a cut-off end: Tyto;

- oblique with a cut-off end: Nyctea;

- oblique with a rounded end: Athene;

- end curving upwards: Bubo, Strix aluco, S. nebulosa, S. uralensis, Surnia;

- b: spatium intermetacarpale:

- wide: Aegolius, Nyctea, Otus, Strix aluco, S. nebulosa, S. uralensis;

- medially wide: Bubo, Asio otus, Tyto;

- narrow: Asio flammeus, Athene, Surnia; 
- c: end of the metacarpus majus:

- flat: Aegolius, Asio flammeus, A. otus, Athene, Tyto;

- protrusive: Bubo, Nyctea, Otus, Strix aluco, S. nebulosa, S. uralensis, Surnia

7. Phalanx proximalis digiti majoris (Plate 12)

The first phalanx of the second finger of the wing was unjustly not examined by the experts, despite it being one of the easiest-to-define skeletal parts with the most typical diagnostic characteristics.

- a: proximal end:

- straight: Athene, Tyto;

- wavy: Bubo, Nyctea, Otus, Strix uralensis;

- protuberant: Aegolius, Asio flammeus, A. otus, Strix aluco, S. nebulosa, Surnia;

- b: the distal end is:

- dented: Asio flammeus, A. otus, Bubo, Nyctea, Otus, Surnia;

- protuberant: Aegolius, Athene;

- wavy: Strix aluco, S. nebulosa, S. uralensis, Tyto;

- c: the proximal end of the dorsal side is:

- rounded: Athene, Tyto;

- cut-off: Aegolius, Bubo, Strix nebulosa;

- proximally provided with a pointed projection: Asio flammeus, A. otus, Nyctea, Otus, Strix aluco, Strix uralensis, Surnia

\section{Femur (Plate 13)}

The morphological homogeneity is significant in the case of this skeletal part. Only the distal epiphysis contains characteristics fit for distinction.

- a: condylus lateralis:

- laterally rounded: Aegolius, Asio otus, Nyctea, Strix uralensis, Tyto;

- laterally protrusive: Asio flammeus, Athene, Bubo, Glaucidium, Otus, Strix aluco;

- b: sulcus intercondylaris:

- shallow: Aegolius, Athene;

- medially deep: Asio flammeus, A. otus, Bubo, Glaucidium, Otus, Strix uralensis, Tyto;

- deep: Nyctea;

- asymmetrical: Strix aluco

\section{Tibiotarsus (Plate 14)}

The skeletal part has a high degree of homogeneity, the species can only be concluded based on its size. The fibula is typically grown to the tibiotarsus close to the distal epiphysis. On the distal epiphysis of the tibiotarsus, the pons supratendineus is missing, the sulcus extensorius (a) is wide and deep, the two epicondylus (lateralis and medialis) (b, c) are poorly developed, as is the tuberculum retinaculum musculi fibularis (d). Above the incisura intercondylaris (e) on the caudal side, a wide hole (fossa flexoria) can be found. 


\section{Tarsometatarsus (Plate 15)}

Primarily, the tarsometatarsus changes relative to species. Morphological differences are less typical, and they can mostly be found on the distal epiphysis. The trochlea metatarsi IV.

(c) has a typical shape.

- a: characteristics of the diaphysis:

- rather short and stout: Surnia;

- stout: Aegolius, Bubo, Glaucidium, Nyctea;

- medially stout and long: Asio flammeus, A. otus, Athene, Otus, Strix aluco;

- long and slim: Tyto;

- b: trochlea metatarsi II.:

- elongated: Strix aluco;

- clublike: Glaucidium, Nyctea, Surnia;

- blunt cone: Aegolius, Asio flammeus, A. otus, Athene, Bubo, Otus, Tyto

\section{Distal phalanges (Plate 16)}

Since one leg contains 4 distal phalanges, those can be distinguished based on the shapes of (cotyla articularis) (b) as well as tuberculum extensorium (a) and tuberculum flexorium (c). Seven phalanges can also be identified in a similar manner. This, however, requires an appropriate comparative collection to accomplish. In the tables and figures, we only show a distal phalanx of each species for information purposes, without their exact classification. The available collection only made this possible in case of the Eurasian Eagle-owl (see Plate 2 ). The fact that the distal phalanges of the 4 toes can differ in size and somewhat in appearance has to be taken into account. Thus, the characteristics presented here are provided for information purposes only, as well as their lengths in the size table.

Plate 3. helps understand the size charts.

\section{Acknowledgements}

The author wishes to express his deep gratitude to Mihály Gasparik for access in recent bird bone collection in the Natural History Museum of Hungary, to József Vuts and Lóránd Abos for the language revision. 


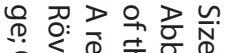

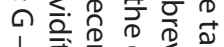

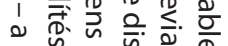

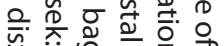
국을 은

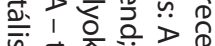

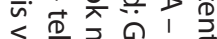

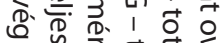

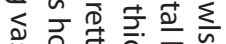

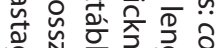
造

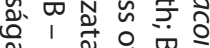
بِ بِ

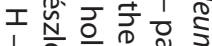
1 N D

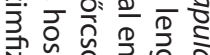
공ํำ

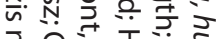
उิำ

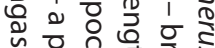

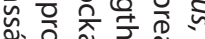
은.

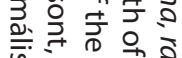

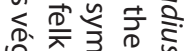

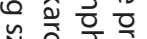

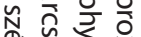

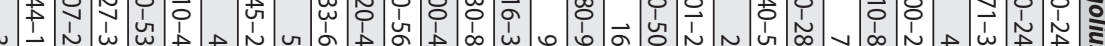

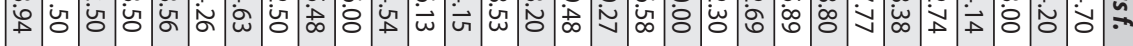

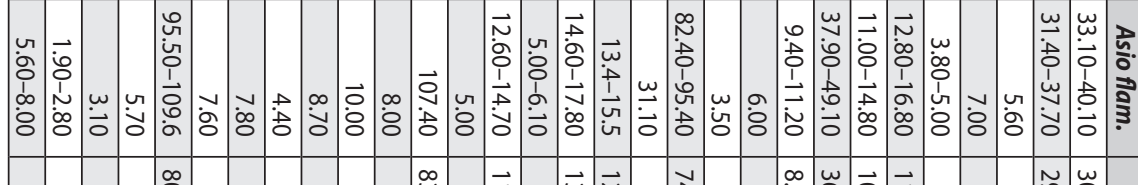

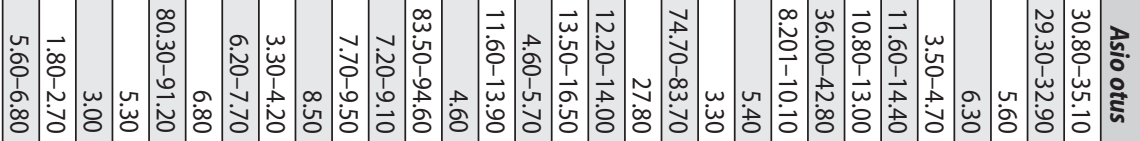

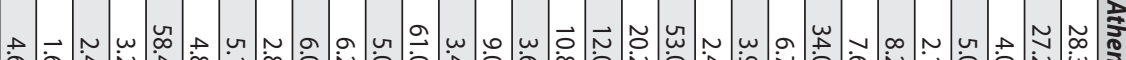
के

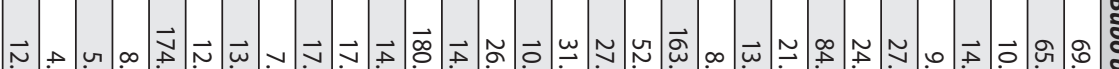
в

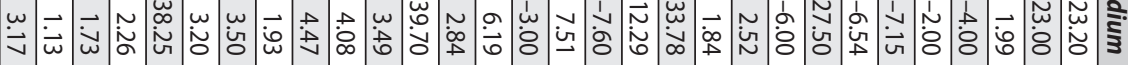

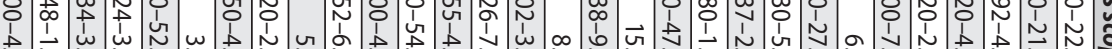

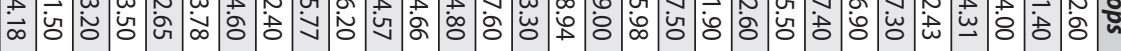

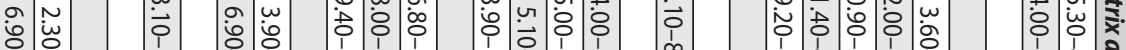

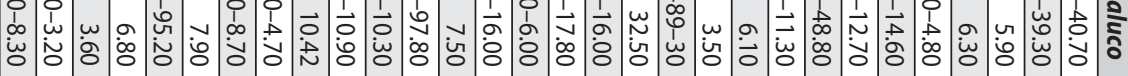

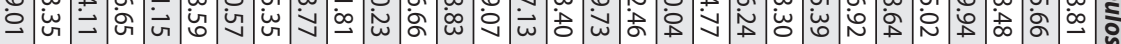

\section{$\overrightarrow{\vec{\nabla}} \quad \overrightarrow{\vec{\nabla}}$} $\overrightarrow{\vec{v}}$

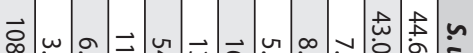

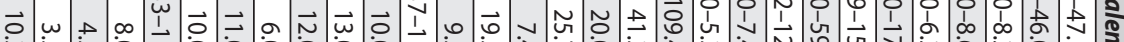

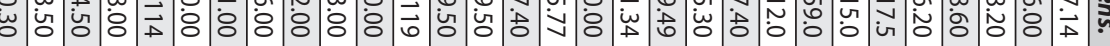

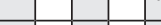

$\pi \rightarrow$

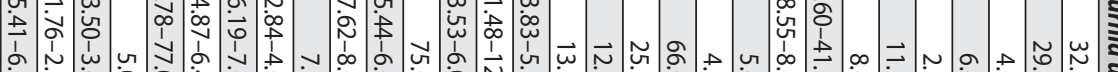

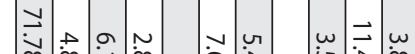

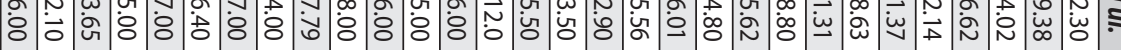


离

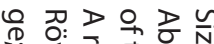

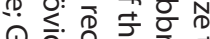
1 辛 号

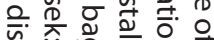

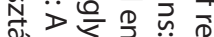

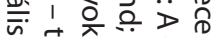
$<$ 贾

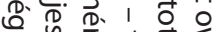
ธ হ

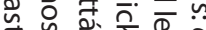

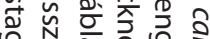

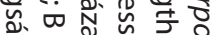
는

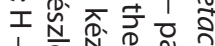

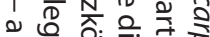
N. \& N 品

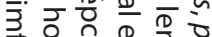
촌 幺ํำ उิी

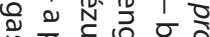

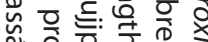
을 즛 으 은

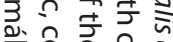
음 응응

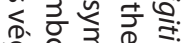

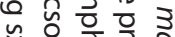

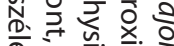
क ज ज ज.

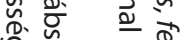
ำ 을

$\checkmark$

은 은

은

ơ

종 जั

চ

6

ป

党

ข้

잉

ता

$\stackrel{D}{D}$

N

D.

约

D

$\nabla \approx$

워ํ

드: त्र̃

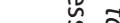

우 용 ริ

믐

ำ ำ కุ่ ปิ

곡

음

D

产

오

穴

ه

은 은

ज.

๙

๒

กิ

气

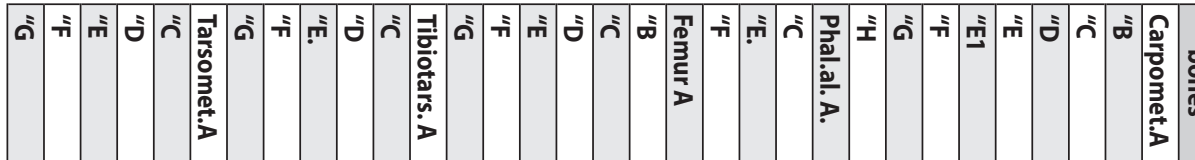

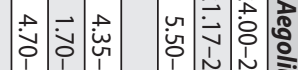

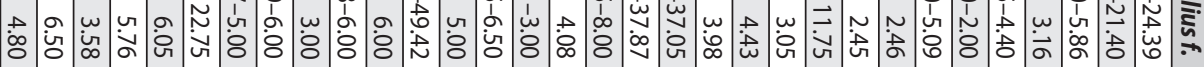

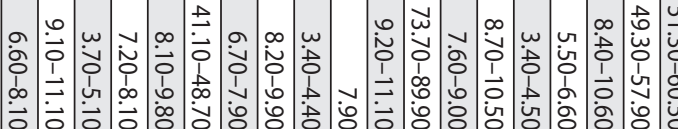

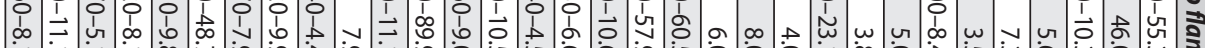

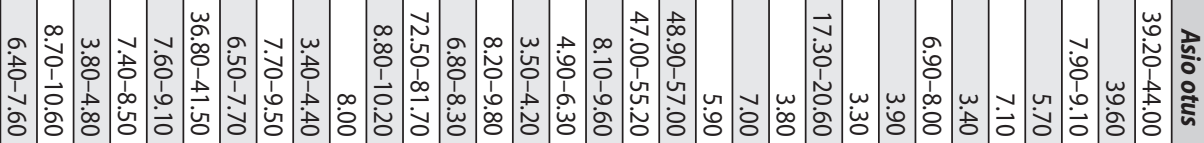

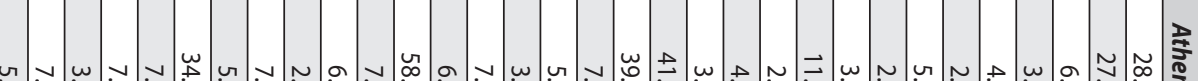

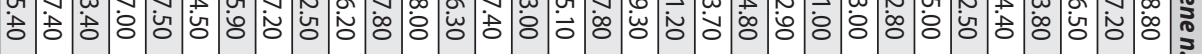

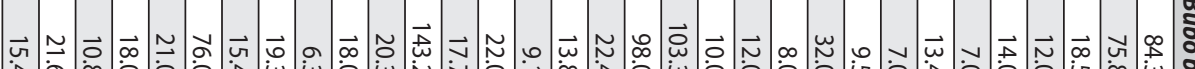
சு

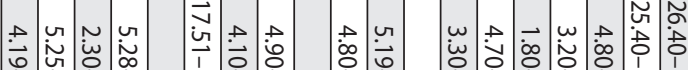

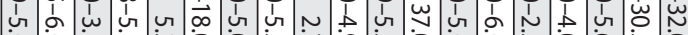

ச 8

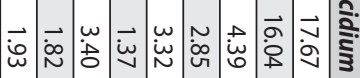

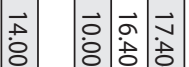

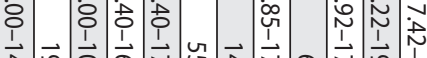

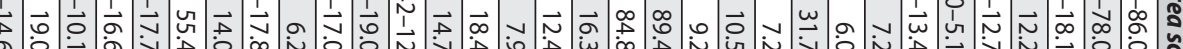

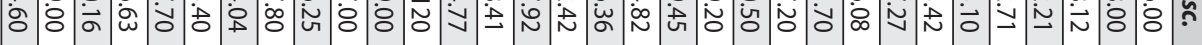

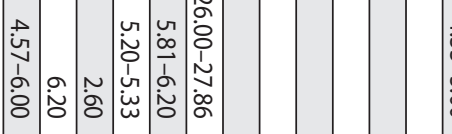

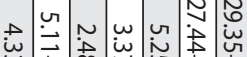

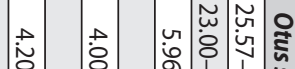

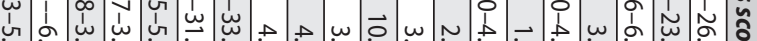

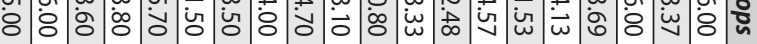

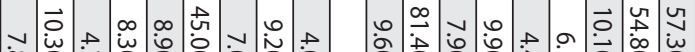

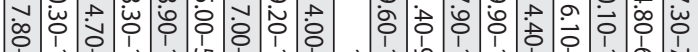

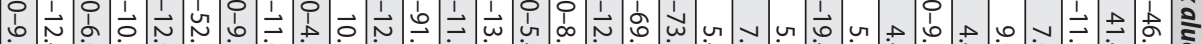

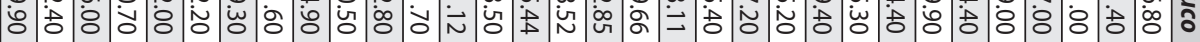

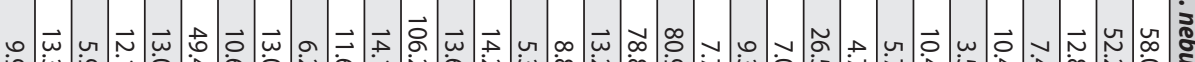

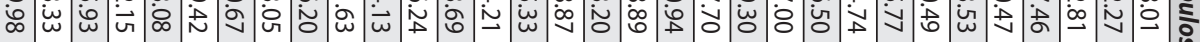

\begin{tabular}{|c|c|c|c|c|c|c|c|c|c|c|c|c|c|c|c|c|c|c|c|c|c|c|c|c|c|c|}
\hline & & & $\begin{array}{l}\vec{E} \\
\text { जे }\end{array}$ & & & & & & & $\vec{\omega}$ & ज̆ & 寍 & 8 & & 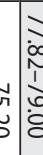 & ì & & $\ddot{d}$ & 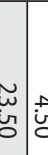 & $\ddot{~}$ & & & & & & 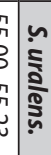 \\
\hline & & & & & N & d & $\vec{H}$ & 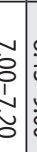 & 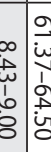 & ळे & 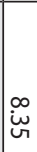 & 莟 & $\stackrel{\vec{b}}{\overrightarrow{0}}$ & 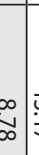 & $\overrightarrow{\vec{v}} \mid \vec{t}$ & $\underset{\sim}{\mathbf{N}}$ & $\mid \begin{array}{c}u \\
\dot{w} \\
u\end{array}$ & $\stackrel{\omega}{\vec{\perp}}$ & $\begin{array}{c}\vec{u} \\
\dot{\omega}\end{array}$ & 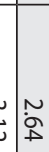 & $\left|\begin{array}{l}a \\
\dot{0} \\
\vdots \\
\hat{o} \\
\dot{o}\end{array}\right|$ & 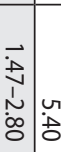 & $\underset{\dot{\infty}}{w}$ & 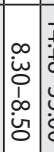 & & 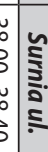 \\
\hline & 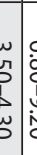 & & 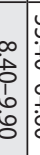 & & & $\begin{array}{l}0 \\
T \\
\end{array}$ & \% & & Pُ & \begin{tabular}{l}
\multirow{0}{0}{} \\
\\
¿ें
\end{tabular} & $\begin{array}{l}\dot{0} \\
1 \\
\end{array}$ & $\begin{array}{l}\omega \\
\infty \\
0 \\
1 \\
+ \\
\\
\end{array}$ & $\begin{array}{l}\overrightarrow{0} \\
\dot{8} \\
\vdots \\
\dot{8} \\
\dot{8}\end{array}$ & $\begin{array}{l}0 \\
0 \\
0 \\
1 \\
0 \\
0 \\
0\end{array}$ & 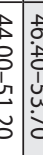 & $\ddot{d}$ & 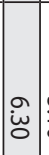 & 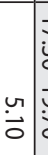 & $\begin{array}{l}\overrightarrow{\vec{v}} \\
\vec{u} \\
\underline{u} \\
\overrightarrow{0} \\
0\end{array}$ & $\vec{b}$ & 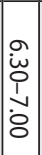 & $\underset{\omega}{\omega}$ & $\dot{8}$ & $\left|\begin{array}{l|}\infty \\
\dot{\vec{p}} \\
\dot{0} \\
0 \\
\dot{0} \\
0\end{array}\right|$ & 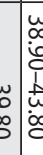 & 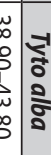 \\
\hline
\end{tabular}




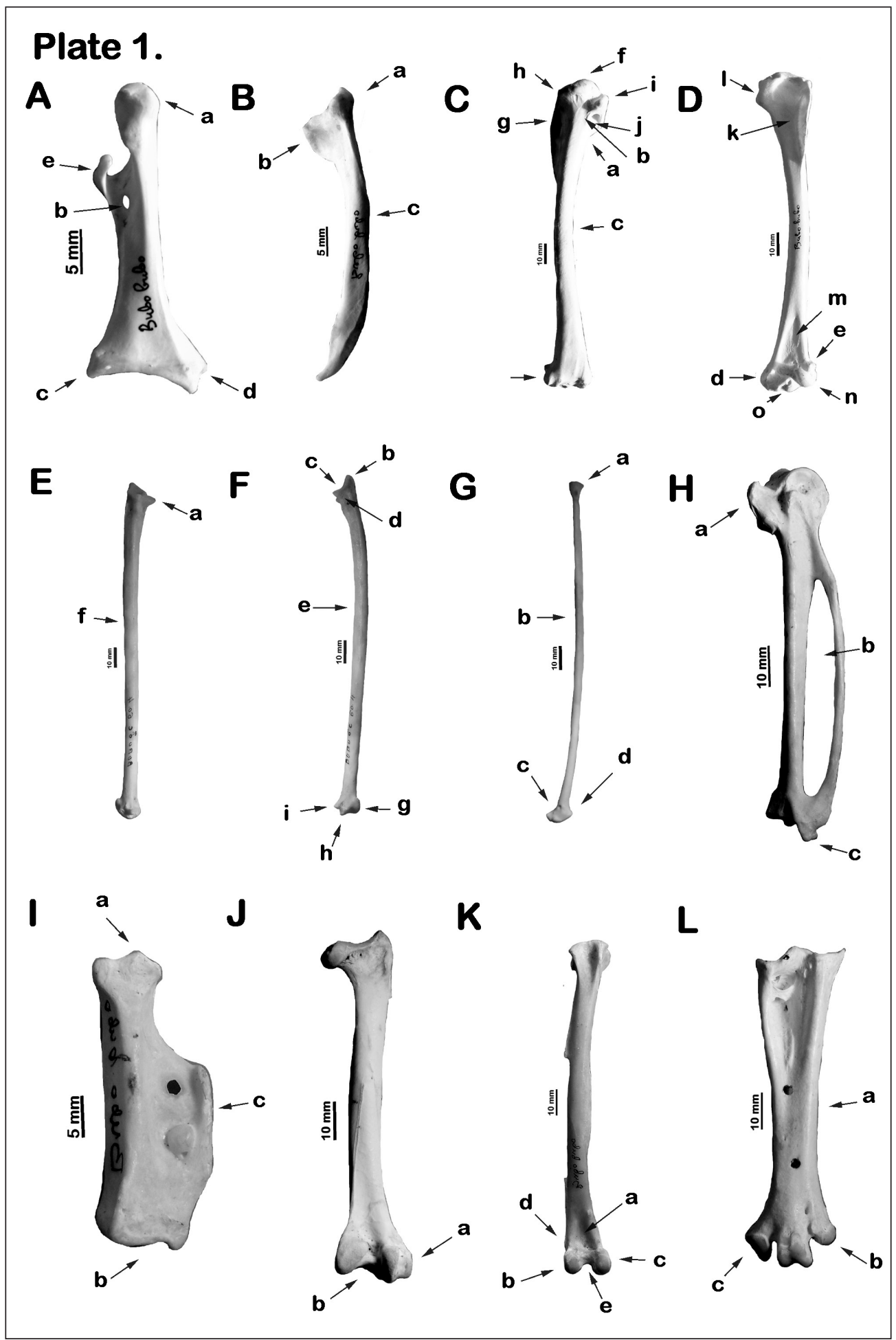


Plate 1.

Bubo bubo (Linnaeus, 1758) osteology characters:

A. Coracoideum - a. processus acrocoracoidalis; b. foramen procoracoideus; c. angulus medialis;

d. processus lateralis; e. processus procoracoidalis.

B. Scapula - a. acromion; b. processus articularis humeralis; c. corpus scapulae.

C, D. Humerus - a. crus ventrale fossae; b. crus dorsale fossae; c. corpus humeri; d. epicondylus ventralis; e. processus supracondylaris dorsalis; f. caput humeri; g. crista deltopectoralis; h. tuberculum dorsale; i. tuberculum ventrale; j. fossa pneumotricipitalis; $\mathrm{k}$. impressio coracobrachialis; I. sulcus transversus; m. fossa musculi brachialis; n. condylus ventralis; o. condylus dorsalis.

E, F. Ulna - a. apophysis glenoidalis externa; b. olecranon; c. apophysis glenoidalis interna; d. impressio brachialis; e. corpus ulnae; f. papillae remigialis (dorsalis and ventralis); g. condylus dorsalis ulnaris; h. condylus ventralis ulnaris; i. tuberculum carpale.

G. Radius - a. tuberculum bicipitale; b. corpus radii; c. tuberculum aponeurosis ventrale; $d$. tuberculum aponeurosis dorsale.

H. Carpometacarpus - a. processus extensorius; b. spatium intermetacarpale; c. facies articularis digitalis minor.

I. Phalanx proximalis digiti majoris - a. proximal end; b. distal end; c. proximal end of the lateral side. J. Femur - a. condylus lateralis; b. sulcus intercondylaris.

K. Tibiotarsus - a. sulcus extensorius; b. epicondylus lateralis; c. epicondylus medialis; d. tuberculum retinaculum musculi fibularis; e. incisura intercondylaris.

L. Tarsometatarsus - a. diaphysis; b. trochlea metatarsi Il.; c. trochlea metatarsi IV.

1. táblakép

Bubo bubo (Linnaeus, 1758) csonttani jellegek:

A. Hollócsőrcsont - a. processus acrocoracoidalis; b. foramen procoracoideus; c. angulus medialis;

d. rocessus lateralis; e. processus procoracoidalis.

B. Lapocka - a. acromion; b. processus articularis humeralis; c. corpus scapulae.

C, D. Felkarcsont - a. crus ventrale fossae; b. crus dorsale fossae; c. corpus humeri; d. epicondylus ventralis;

e. processus supracondylaris dorsalis; f. caput humeri; g. crista deltopectoralis; h. tuberculum dorsale;

i. tuberculum ventrale; j. fossa pneumotricipitalis; k. impressio coracobrachialis; I. sulcus transversus;

m. fossa musculi brachialis; $\mathrm{n}$. condylus ventralis; o. condylus dorsalis.

E, F. Singcsont - a. apophysis glenoidalis externa; b. olecranon; c. apophysis glenoidalis interna; d. impressio brachialis; e. corpus ulnae; f. papillae remigialis (dorsalis és ventralis); g. condylus dorsalis ulnaris; h. condylus ventralis ulnaris; i. tuberculum carpale.

G. Orsócsont - a. tuberculum bicipitale; b. corpus radii; c. tuberculum aponeurosis ventrale; d. tuberculum aponeurosis dorsale.

H. Kézközépcsont - a. processus extensorius; b. spatium intermetacarpale; c. a metacarpus majus disztális vége.

I. A nagy kézujj első ujjperce - a. proximális vég; b. disztális vég; c. dorsalis oldal proximális vége.

J. Combcsont - a. condylus lateralis; b. sulcus intercondylaris.

K. Lábszárcsont - a. sulcus extensorius; b. epicondylus lateralis; c. epicondylus medialis; d. tuberculum retinaculum musculi fibularis; e. incisura intercondylaris.

L. Csüd - a. diafizis; b. trochlea metatarsi Il.; c. trochlea metatarsi IV. 


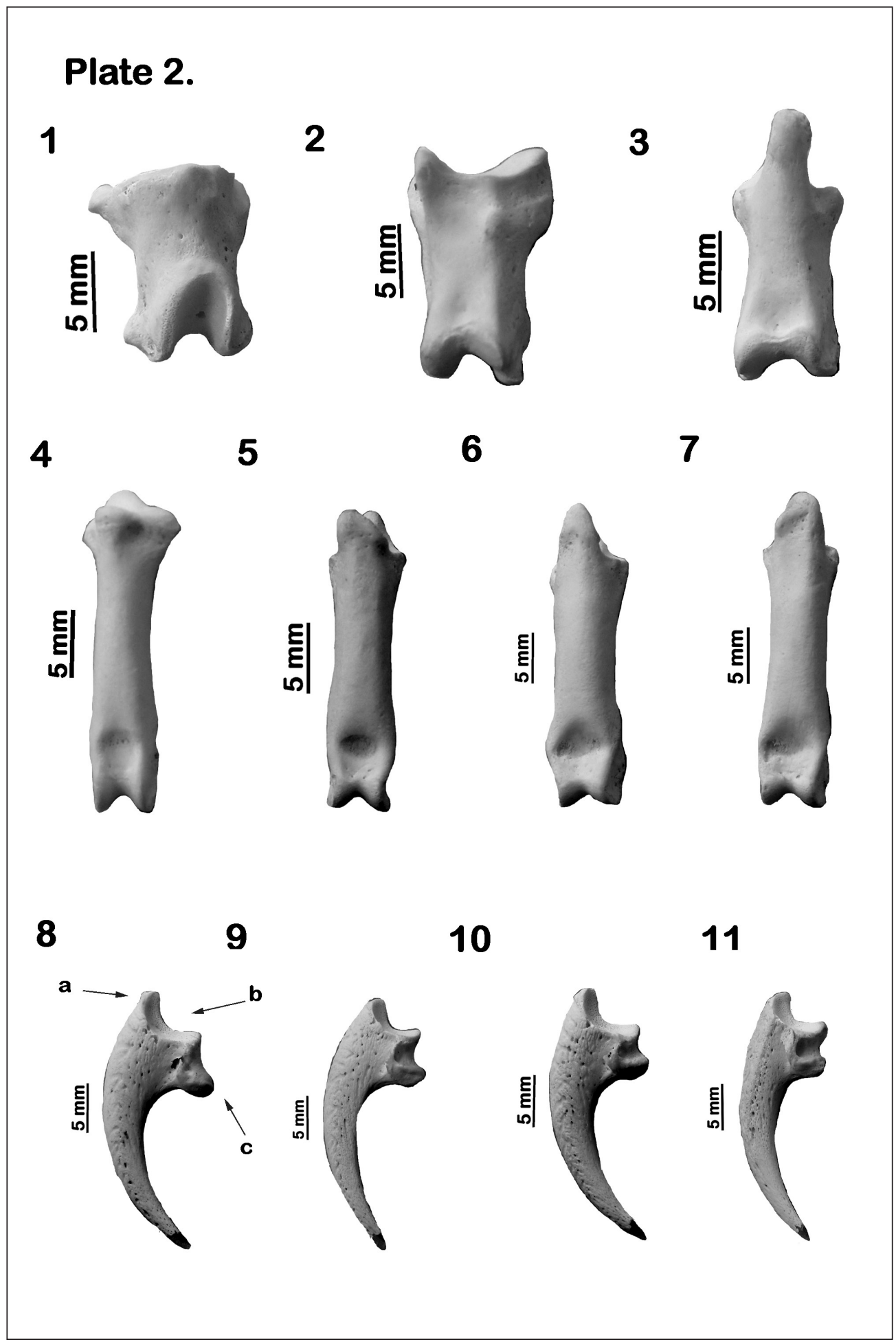


Plate 2.

Bubo bubo (Linnaeus, 1758) osteology characters. Distal phalanges and claws: a. tuberculum extensorium; b. cotyla articularis; c. tuberculum flexorium.

Phalanx I. digiti 2.; 2. Phalanx I. digiti 3.; 3. Phalanx II. digiti 3.; 4. Phalanx I. digiti 1.; 5. Phalanx II. digiti 2.; 6. Phalanx III. digiti 3.; 7. Phalanx IV. digiti 4.; 8. Phalanx II. digiti 1.; 9. Phalanx III. digiti 2.; 10. Phalanx IV. digiti 3.; 11. Phalanx V. digiti 4.

\section{2. táblakép}

Bubo bubo (Linnaeus, 1758) csonttani jellegek. Ujjpercek és karomcsontok: a. tuberculum extensorium; b. cotyla articularis; c. tuberculum flexorium.

Phalanx I. digiti 2.; 2. Phalanx I. digiti 3.; 3. Phalanx II. digiti 3.; 4. Phalanx I. digiti 1.; 5. Phalanx II. digiti 2.; 6. Phalanx III. digiti 3.; 7. Phalanx IV. digiti 4.; 8. Phalanx II. digiti 1.; 9. Phalanx III. digiti 2.; 10. Phalanx IV. digiti 3.; 11. Phalanx V. digiti 4. 


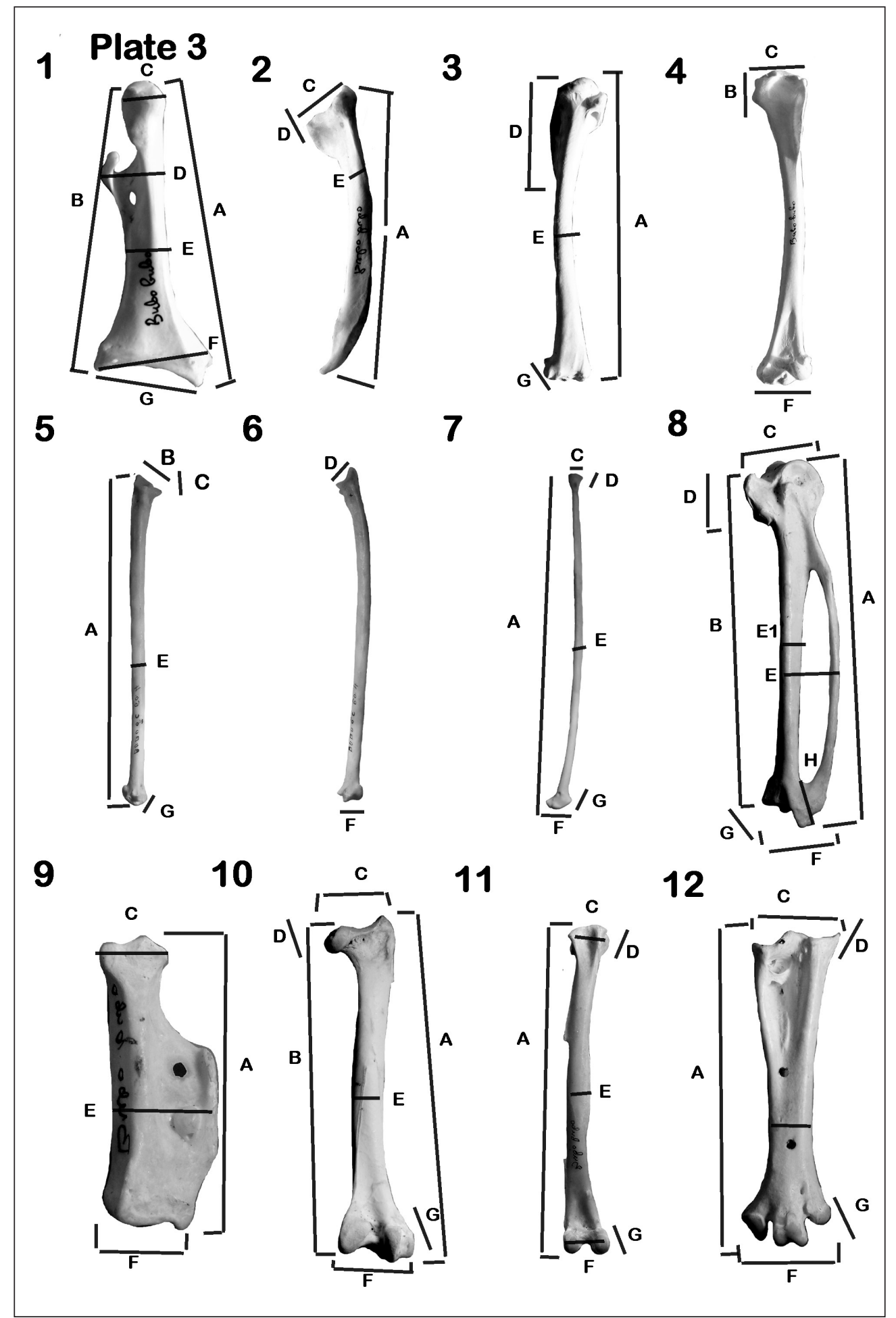


Plate 3.

Measurements methods of bones:

1. Coracoideum:

A. total length;

B. partial length;

C. breadth of the proximal end;

D. breadth of the corpus and processus procoracoidalis;

E. breadth of the corpus;

F. total breadth of the distal end;

G. partial breadth of the distal end

\section{Scapula:}

A. total length;

B. length of the proximal end;

C. partial length;

D. breadth of the proximal end;

E. breadth of the corpus

\section{3-4. Humerus:}

A. total length;

B. partial length1.;

C. breadth of the proximal end;

D. partial length 2.;

E. breadth of the corpus;

F. breadth of the distal end;

G. thickness of the distal end

\section{5-6. Ulna:}

A. total length;

B. length of the proximal epiphysis;

C. breadth of the proximal end;

D. diagonal breadth of the proximal end;

E. breadth of the corpus;

F. breadth of the distal end;

G. thickness of the distal end

\section{Radius:}

A. total length;

$B$ length of the proximal epiphysis;

C. breadth of the proximal end;

D. thickness of the proximal end;

E. breadth of the corpus;

F. breadth of the distal end;

G. thickness of the distal end

\section{Carpometacarpus:}

A. total length;

B. partial length;

C. breadth of the proximal end;

D. length of the processus extensorius:

E. breadth of the corpus;

E1: breadth of the metacarpus majus;
F. breadth of the distal end;

G. thickness of the distal end;

$\mathrm{H}$. length of the symphysis

9. Phalanx proximalis digiti majoris:

A. total length;

C. breadth of the proximal end;

E. breadth of the corpus;

F. breadth of the distal end

10. Femur:

A. total length;

B. partial length;

C. breadth of the proximal end;

D. thickness of the proximal end;

E. breadth of the corpus;

F. breadth of the distal end;

G. thickness of the distal end

11. Tibiotarsus:

A. total length;

C. breadth of the proximal end;

D. thickness of the proximal end;

E. breadth of the corpus;

F. breadth of the distal end;

G. thickness of the distal end

12. Tarsometatarsus:

A. total length;

C. breadth of the proximal end;

D. thickness of the proximal end;

E. breadth of the corpus;

F. breadth of the distal end;

G. thickness of the distal end

3. Táblakép

A csontok mérési mintái:

1. Hollócsőrcsont:

A. teljes hossz;

B. részleges hossz;

C. proximális vég szélessége;

D. proximális vég átlós szélessége;

E. a test szélessége;

F. a disztális vég szélessége;

G. a disztális vég vastagsága

2. Lapockacsont:

A. teljes hossz;

B. részleges hossz;

C. proximális vég szélessége;

D. proximális vég átlós szélessége;

E. a test szélessége 
3-4. Felkarcsont:
A. teljes hossz;
B. részleges hossz 1.;
C. proximális vég szélessége;
D. részleges hossz 2.;
E. a test szélessége;
F. a disztális vég szélessége;
G. a disztális vég vastagsága

\section{5-6. Singcsont:}

A. teljes hossz;

B. részleges hossz;

C. proximális vég szélessége;

D. proximális vég átlós szélessége;

E. a test szélessége;

F. a disztális vég szélessége;

G. a disztális vég vastagsága

\section{Orsócsont:}

A. teljes hossz;

B. részleges hossz;

C. proximális vég szélessége;

D. proximális vég vastagsága;

E. a test szélessége;

F. a disztális vég szélessége;

G. a disztális vég vastagsága

8. Kézközépcsont:

A. teljes hossz;

B. részleges hossz;

C. proximális vég szélessége;

D. a processus flexorius hossza;

E. a test szélessége;

E1 a metacarpus majus vastagsága;

F. a disztális vég szélessége;

G. a disztális vég vastagsága;

H. a szimfizis magassága

9. Kézujjperc (II. ujj, 1. perc):

A. teljes hossz;

C. proximális vég szélessége;

E. a test szélessége;

F. a disztális vég szélessége

10. Combcsont:

A. teljes hossz;

B. részleges hossz;

C. proximális vég szélessége;

D. proximális vég vastagsága;

E. a test szélessége;

F. a disztális vég szélessége;

G. a disztális vég vastagsága
11. Lábszárcsont:

A. teljes hossz;

C. proximális vég szélessége;

D. proximális vég vastagsága;

E. a test szélessége;

F. a disztális vég szélessége;

G. a disztális vég vastagsága

12. Csüd:

A. teljes hossz;

C. proximális vég szélessége;

D. proximális vég vastagsága;

E. a test szélessége;

F. a disztális vég szélessége;

G. a disztális vég vastagsága 


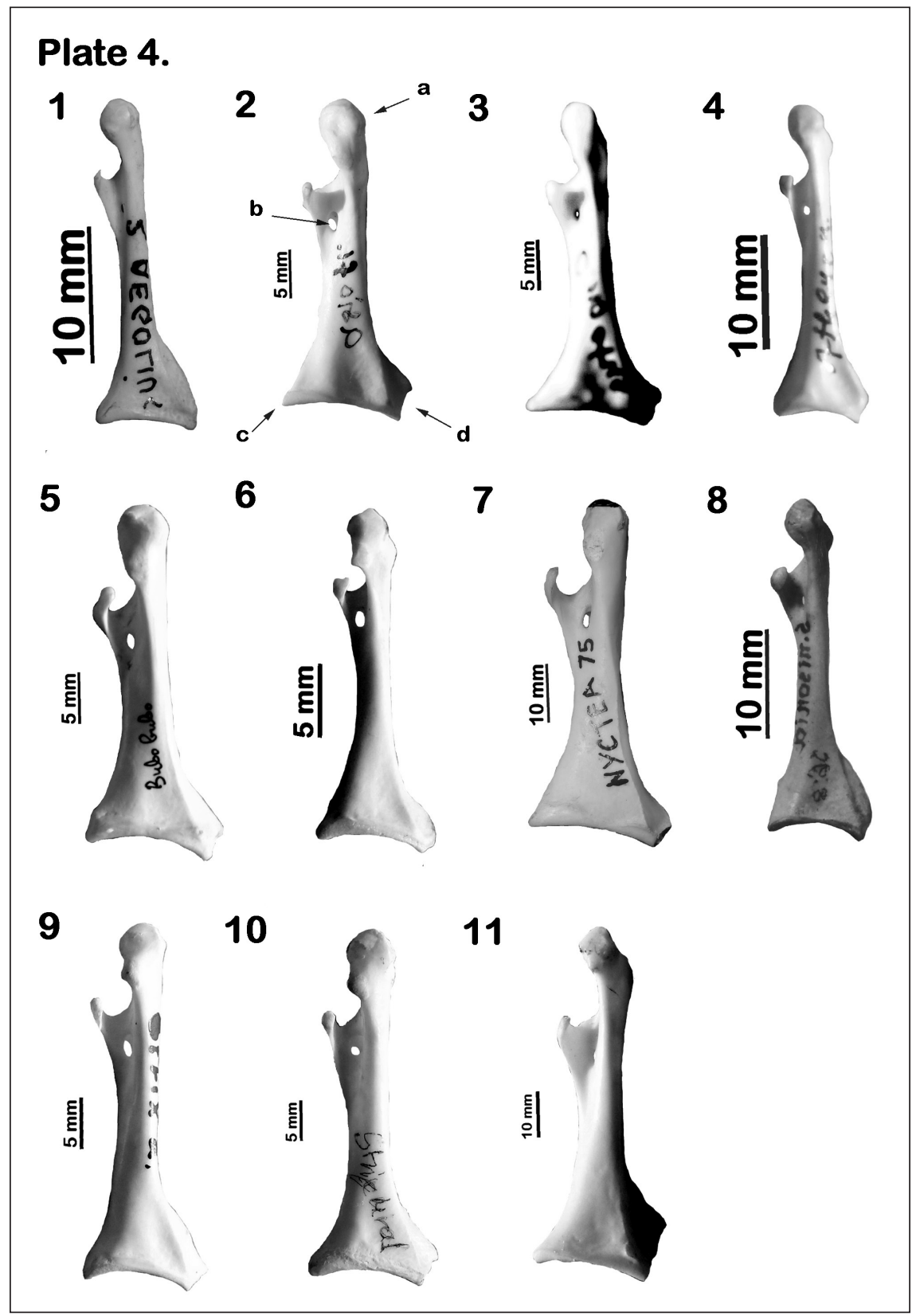

Plate 4.

Left coracoideum (ventral surface) - a. processus acrocoracoidalis; b. foramen procoracoideus; c. angulus medialis; d. processus lateralis

1. Aegolius funereus; 2. Asio flammeus; 3. A. otus; 4. Athene noctua; 5. Bubo bubo; 6. Nyctea scandiaca;

7. Surnia ulula; 8. Otus scops; 9. Strix aluco; 10. S. uralensis; 11. Tyto alba

4. táblakép

Bal oldali hollócsőrcsont (hasi oldal) - a. processus acrocoracoidalis; b. foramen procoracoideus; c. angulus medialis; d. processus lateralis

1. Aegolius funereus; 2. Asio flammeus; 3. A. otus; 4. Athene noctua; 5. Bubo bubo; 6. Nyctea scandiaca;

7. Otus scops; 8. Surnia ulula; 9. Strix aluco; 10. S. uralensis; 11. Tyto alba 
Plate 5.

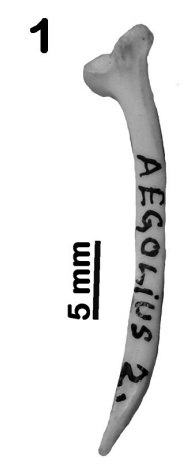

5

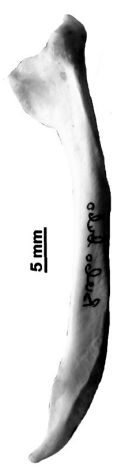

9

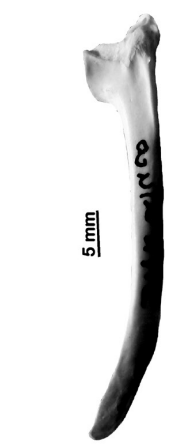

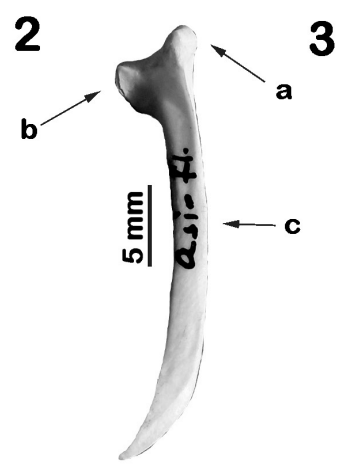

6

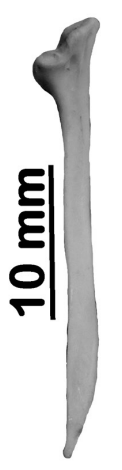

10

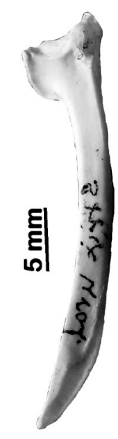

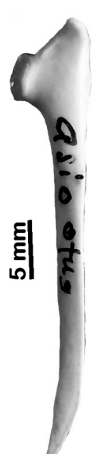

7

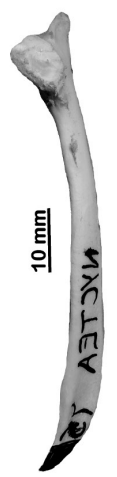

11

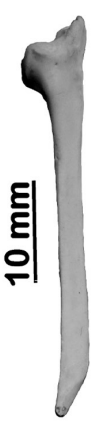

4

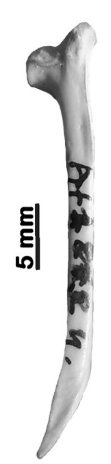

8

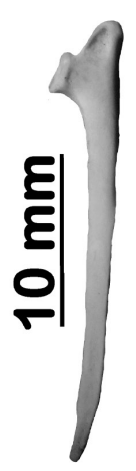

12

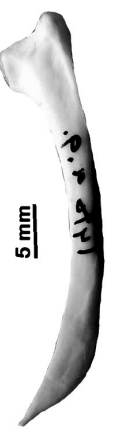

Plate 5.

Left scapula (medial surface) - a. acromion; b. processus articularis humeralis; c. corpus scapulae 1. Aegolius funereus; 2. Asio flammeus; 3. A. otus; 4. Athene noctua; 5. Bubo bubo; 6. Glaucidium passerinum; 7. Nyctea scandiaca; 8 . Surnia ulula; 9 . Otus scops; 10 . Strix aluco; 11. S. uralensis; 12 . Tyto alba

\section{5. táblakép}

Bal oldali lapocka csont (mediális oldal) - a. acromion; b. processus articularis humeralis; c. corpus scapulae

1. Aegolius funereus; 2. Asio flammeus; 3. A. otus; 4. Athene noctua; 5. Bubo bubo; 6. Glaucidium passerinum; 7. Nyctea scandiaca; 8 . Surnia ulula; 9 . Otus scops; 10. Strix aluco; 11. S. uralensis; 12. Tyto alba 


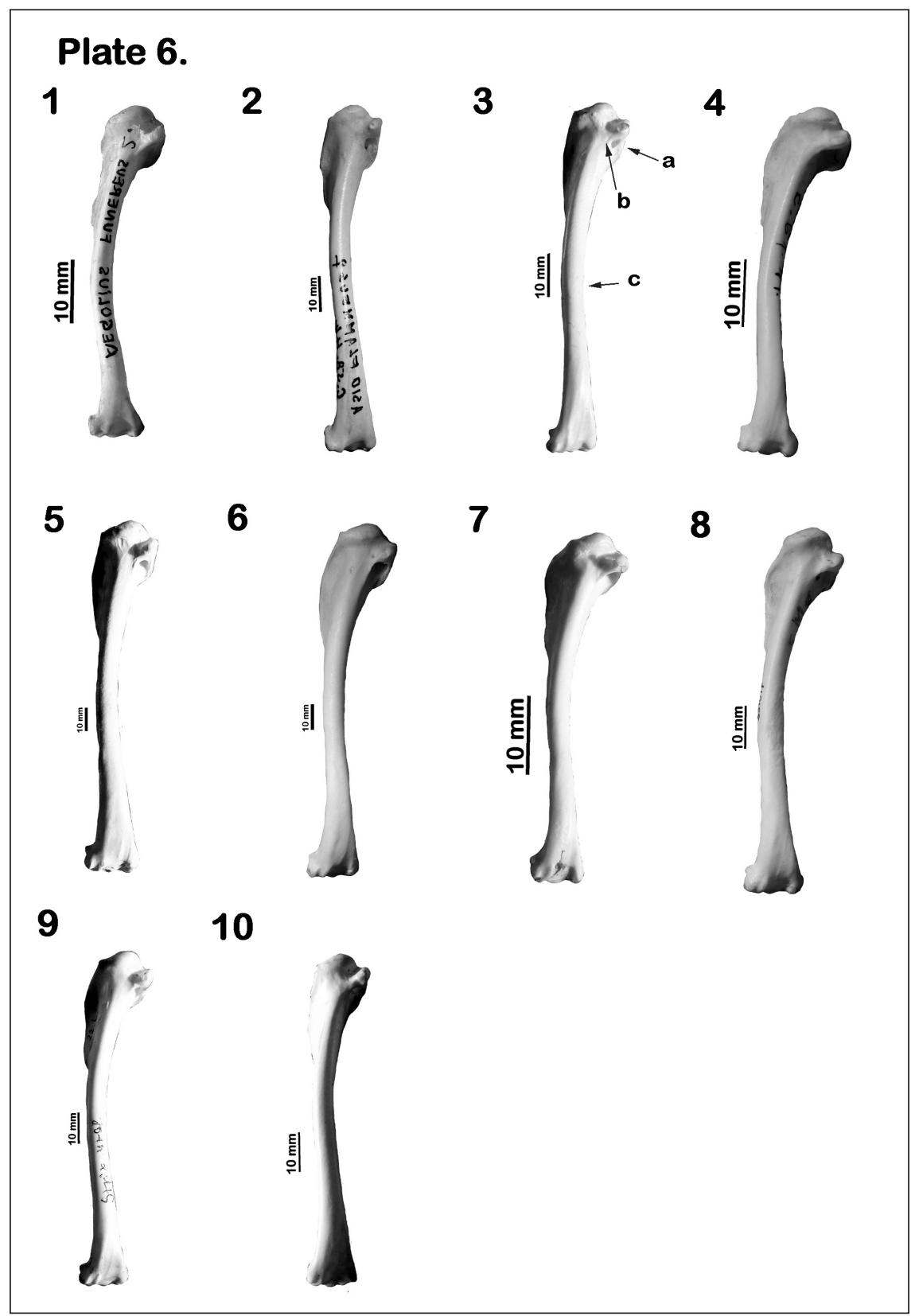

Plate 6.

Left humerus (caudal surface) - a. crus ventrale fossae; b. crus dorsale fossae; c. corpus humeri; d. epicondylus ventralis; e. processus supracondylaris dorsalis

1. Aegolius funereus; 2. Asio flammeus; 3. A. otus; 4. Athene noctua; 5. Bubo bubo; 6. Nyctea scandiaca;

7. Otus scops; 8 . Strix aluco; 9. S. uralensis; 10 . Tyto alba

6. táblakép

Bal oldali felkarcsont (palmáris oldal) - a. crus ventrale fossae; b. crus dorsale fossae; c. corpus humeri; d. epicondylus ventralis; e. processus supracondylaris dorsalis

1. Aegolius funereus; 2. Asio flammeus; 3. A. otus; 4. Athene noctua; 5. Bubo bubo; 6. Nyctea scandiaca;

7. Otus scops; 8. Strix aluco; 9. S. uralensis; 10. Tyto alba 


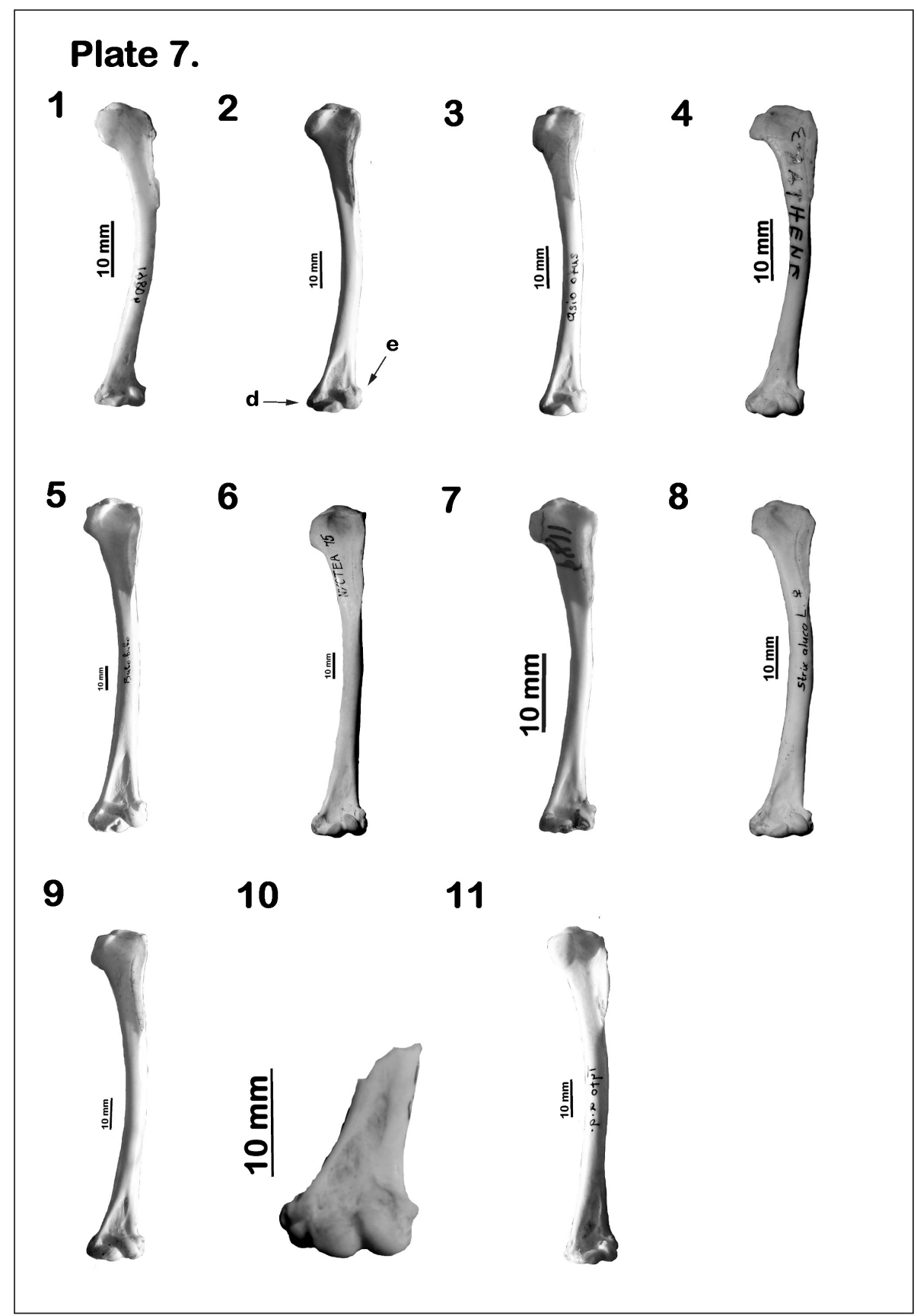

Plate 7.

Left humerus (cranial surface) - d. epicondylus ventralis; e. processus supracondylaris dorsalis 1. Aegolius funereus; 2. Asio flammeus; 3. A. otus; 4. Athene noctua; 5. Bubo bubo; 6. Nyctea scandiaca; 7. Otus scops; 8. Surnia ulula; 9. Strix aluco; 10. S. uralensis; 11 . Tyto alba

\section{7. táblakép}

Bal oldali felkarcsont (dorzális oldal) - d. epicondylus ventralis; e. processus supracondylaris dorsalis 1. Aegolius funereus; 2. Asio flammeus; 3. A. otus; 4. Athene noctua; 5. Bubo bubo; 6. Nyctea scandiaca; 7. Otus scops; 8. Surnia ulula; 9 . Strix aluco; 10. S. uralensis; 11. Tyto alba 


\section{Plate 8.}

1

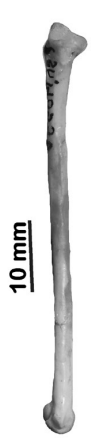

5

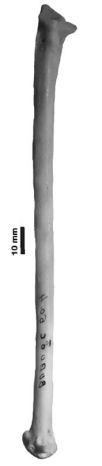

9

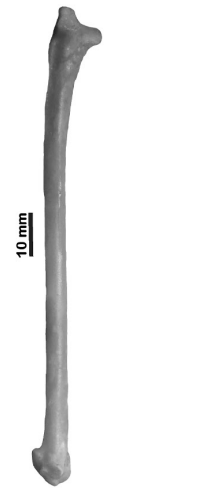

2

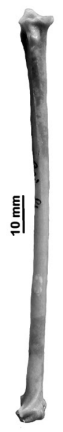

6

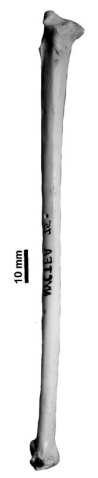

10

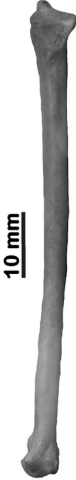

3

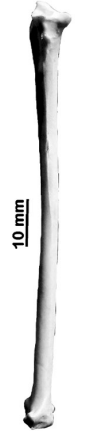

7

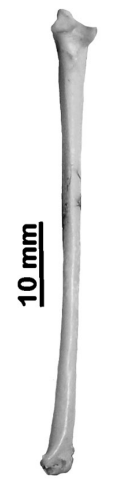

4

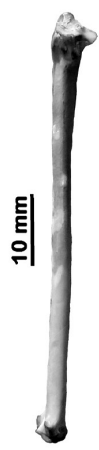

8

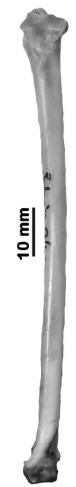

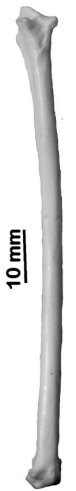

Plate 8.

Left ulna (ventral aspect) - a. apophysis glenoidalis externa

1. Aegolius funereus; 2. Asio flammeus; 3. A. otus; 4. Athene noctua; 5. Bubo bubo; 6. Nyctea scandiaca;

7. Otus scops; 8. Surnia ulula; 9. Strix aluco; 10. S. uralensis; 11 . Tyto alba

\section{8. táblakép}

Bal oldali singcsont (hasi nézet) - a. apophysis glenoidalis externa

1. Aegolius funereus; 2. Asio flammeus; 3. A. otus; 4. Athene noctua; 5. Bubo bubo; 6. Nyctea scandiaca;

7. Otus scops; 8. Surnia ulula; 9. Strix aluco; 10. S. uralensis; 11 . Tyto alba 


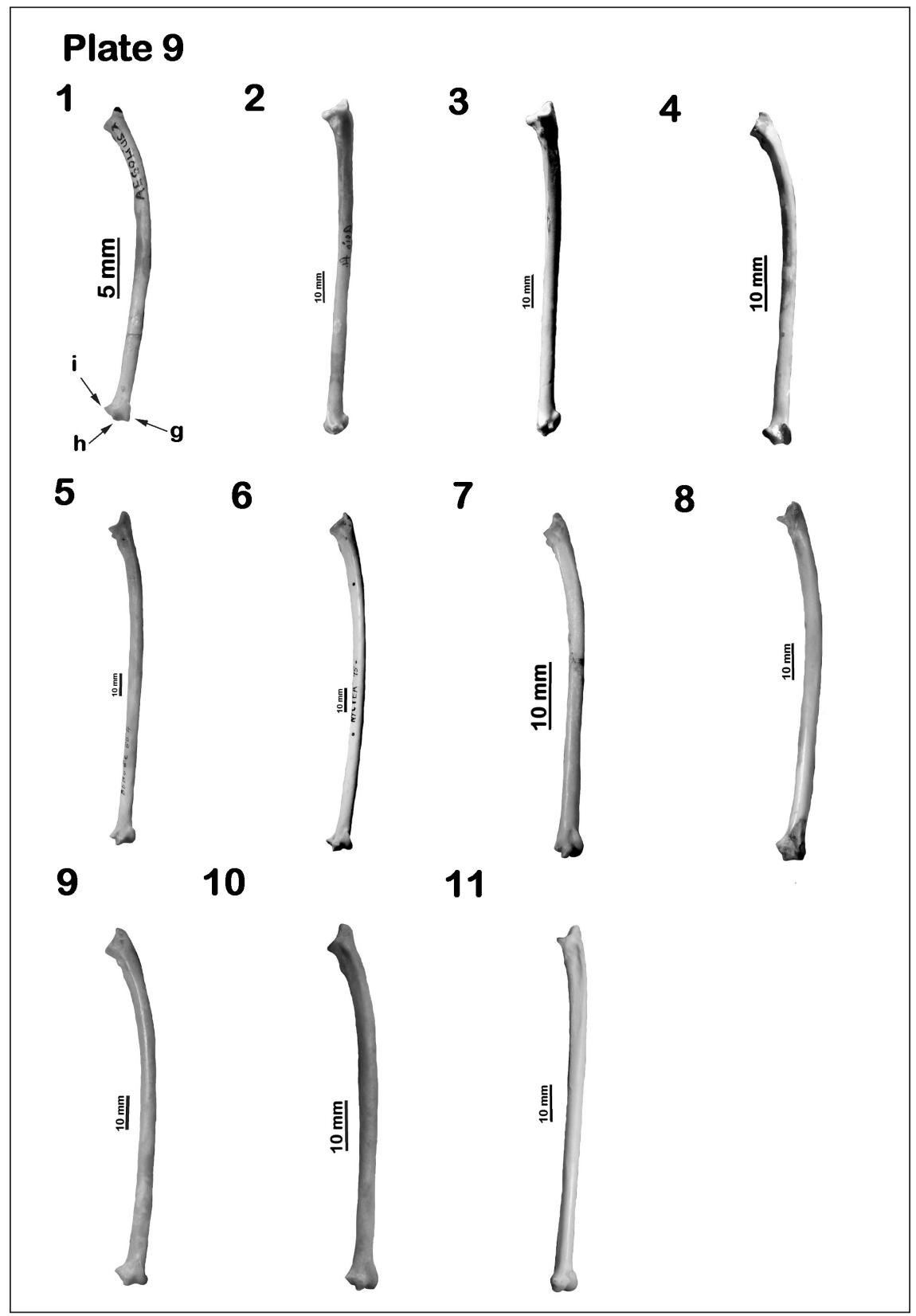

Plate 9.

Left ulna (dorsal aspect)

1. Aegolius funereus; 2. Asio flammeus; 3. A. otus; 4. Athene noctua; 5. Bubo bubo; 6. Nyctea scandiaca; 7. Otus scops; 8. Surnia ulula; 9. Strix aluco; 10. S. uralensis; 11 . Tyto alba

9. táblakép

Bal oldali singcsont (háti nézet)

1. Aegolius funereus; 2. Asio flammeus; 3. A. otus; 4. Athene noctua; 5. Bubo bubo; 6. Nyctea scandiaca;

7. Otus scops; 8 . Surnia ulula; 9 . Strix aluco; 10. S. uralensis; 11 . Tyto alba 


\section{Plate 10}

1

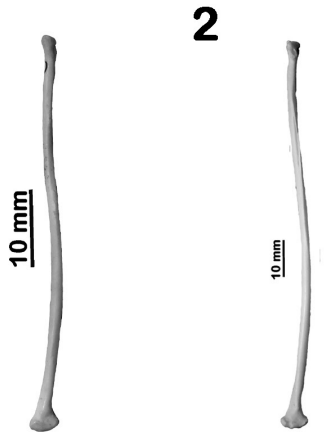

5

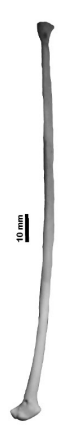

6

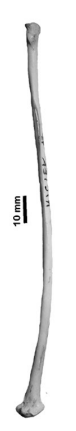

3

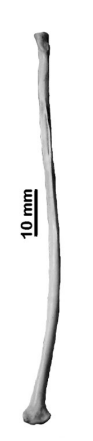

7

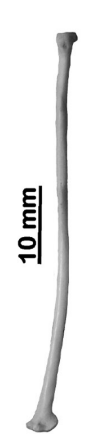

4

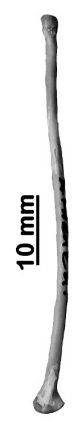

8

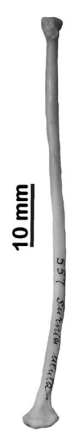

9

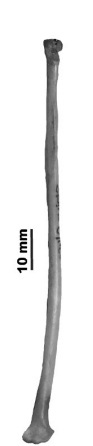

10

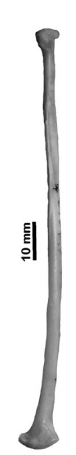

11

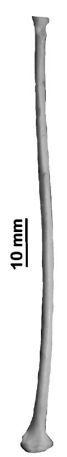

Plate 10.

Left radius (dorsal aspect) - a. tuberculum bicipitale; b. corpus radii; c. tuberculum aponeurosis ventrale; d. tuberculum aponeurosis dorsale

1. Aegolius funereus; 2. Asio flammeus; 3. A. otus; 4. Athene noctua; 5. Bubo bubo; 6. Nyctea scandiaca;

7. Otus scops; 8 . Surnia ulula; 9 . Strix aluco; 10. S. uralensis; 11. Tyto alba

\section{0. táblakép}

Bal oldali orsócsont (háti nézet) - tuberculum bicipitale; b. corpus radii; c. tuberculum aponeurosis ventrale; d. tuberculum aponeurosis dorsale

1. Aegolius funereus; 2. Asio flammeus; 3. A. otus; 4. Athene noctua; 5. Bubo bubo; 6. Nyctea scandiaca;

7. Otus scops; 8. Surnia ulula; 9. Strix aluco; 10. S. uralensis; 11 . Tyto alba 


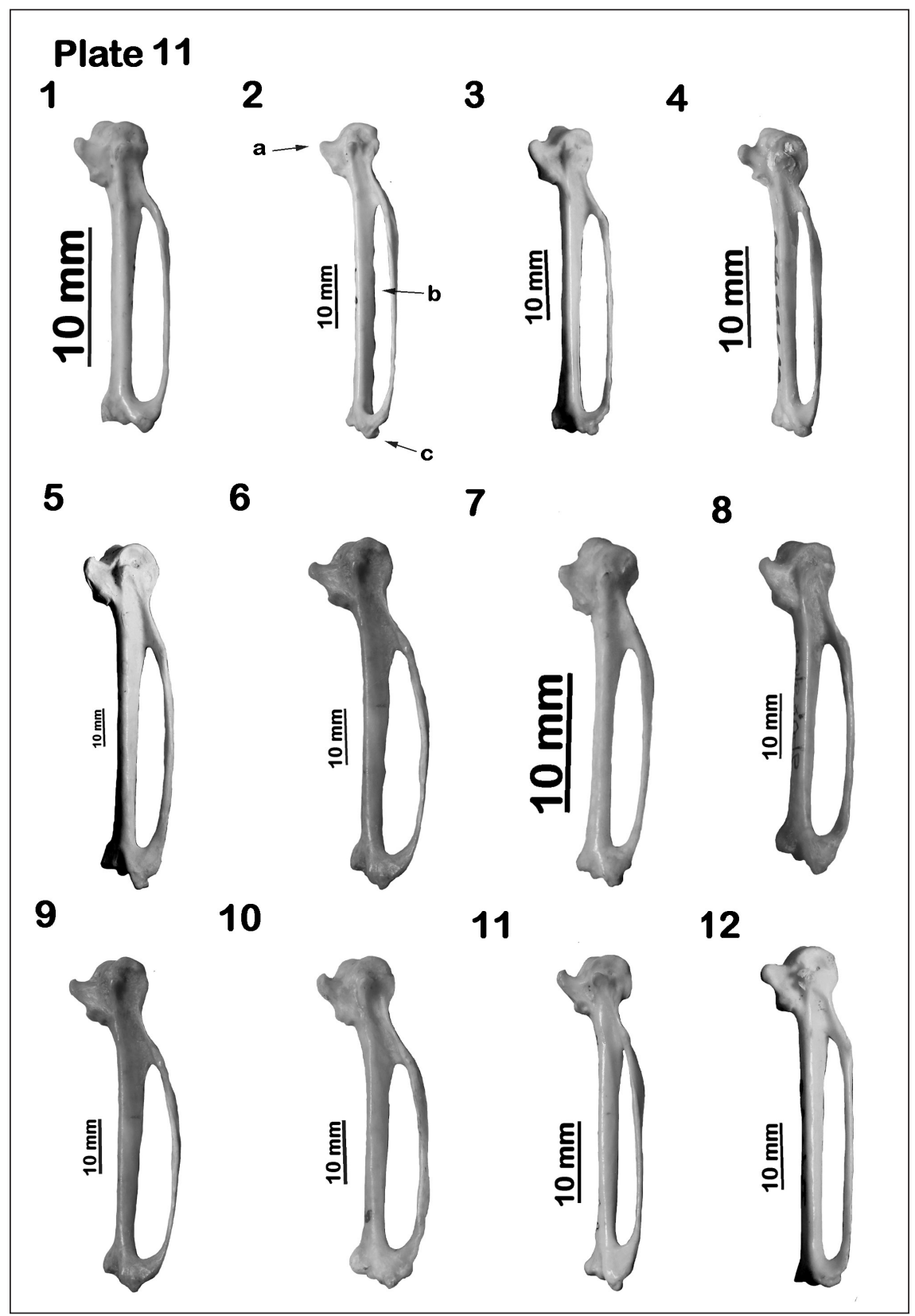

Plate 11.

Left carpometacarpus (ventral aspect) - a. processus extensorius; b. spatium intermetacarpale; c. the distal end of the metacarpus majus

1. Aegolius funereus; 2. Asio flammeus; 3. A. otus; 4. Athene noctua; 5. Bubo bubo; 6. Nyctea scandiaca;

7. Otus scops; 8. Surnia ulula; 9. Strix aluco; 10. S. nebulosa; 11. S. uralensis; 12 . Tyto alba

\section{1. táblakép}

Bal oldali kézközépcsont (hasi nézet) - a. processus extensorius; b. spatium intermetacarpale; c. a metacarpus majus disztális vége

1. Aegolius funereus; 2. Asio flammeus; 3. A. otus; 4. Athene noctua; 5. Bubo bubo; 6. Nyctea scandiaca;

7. Otus scops; 8. Surnia ulula; 9. Strix aluco; 10. S. nebulosa; 11. S. uralensis; 12 . Tyto alba 


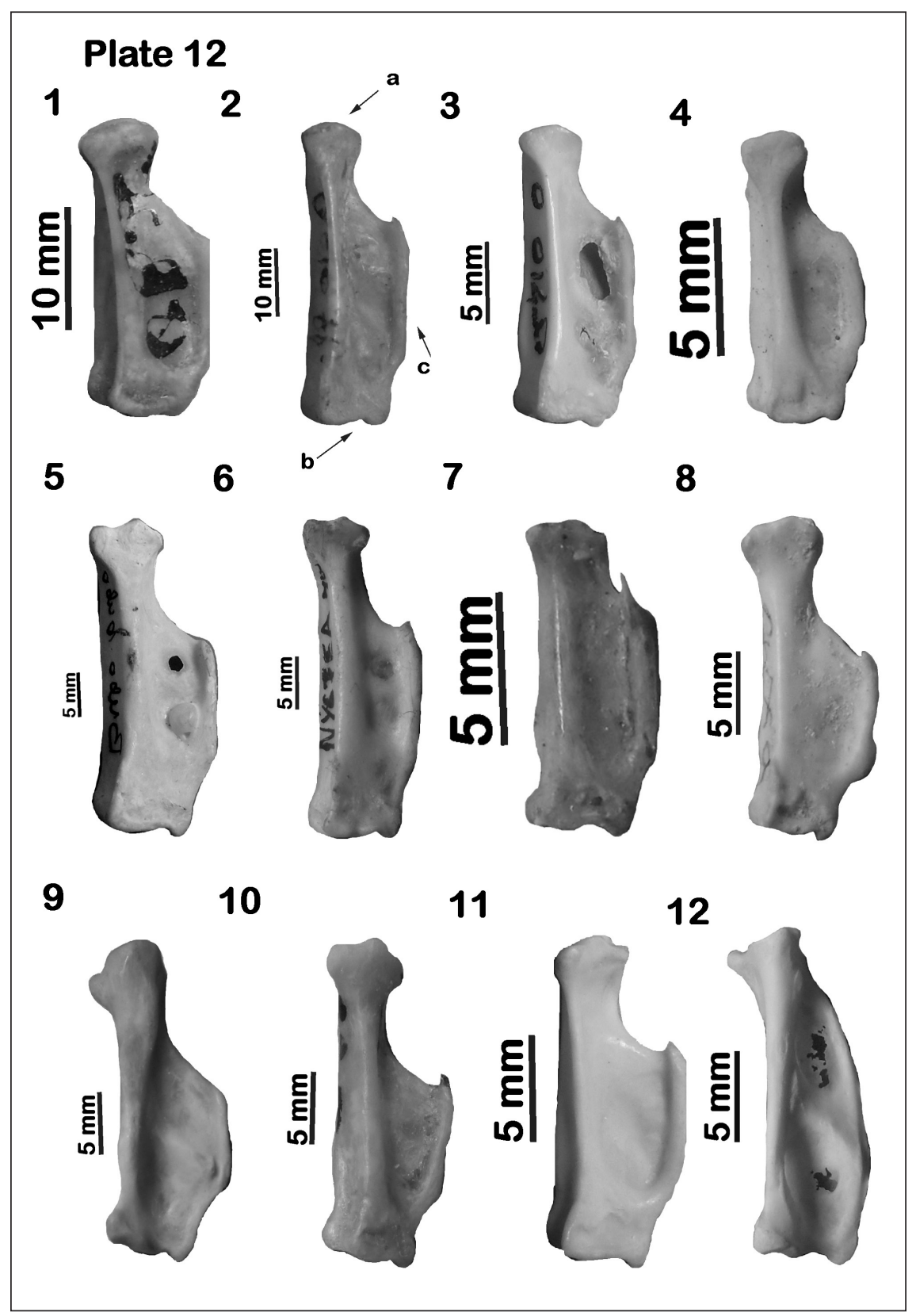

Plate 12.

Left phalanx proximalis digiti majoris (ventral aspect) - a. proximal end; b. distal end; c. proximal end of the lateral side

1. Aegolius funereus; 2. Asio flammeus; 3. A. otus; 4. Athene noctua; 5. Bubo bubo; 6. Nyctea scandiaca;

7. Otus scops; 8. Surnia ulula; 9. Strix aluco; 10. S. nebulosa; 11. S. uralensis; 12 . Tyto alba

12. táblakép

Bal oldali kézujjperc (I. ujjperc, 2. ujj, hasi nézet) - a. proximális vég; b. disztális vég; c. laterális oldal proximális vége

1. Aegolius funereus; 2. Asio flammeus; 3. A. otus; 4. Athene noctua; 5. Bubo bubo; 6. Nyctea scandiaca;

7. Otus scops; 8. Surnia ulula; 9. Strix aluco; 10. S. nebulosa; 11. S. uralensis; 12 . Tyto alba 


\section{Plate 13}

1

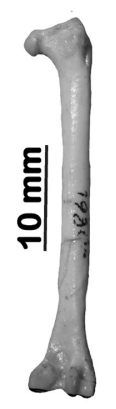

5

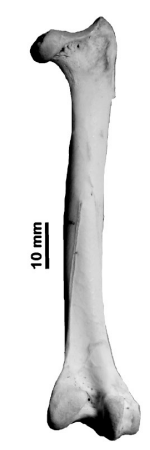

9
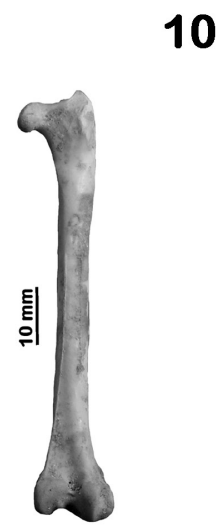

2

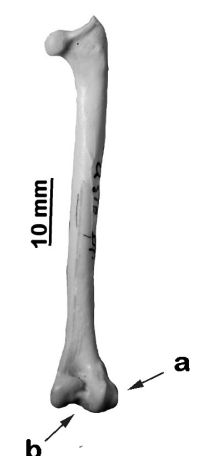

6

b

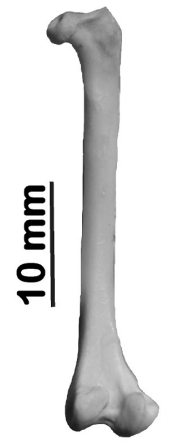

3

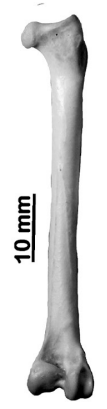

7

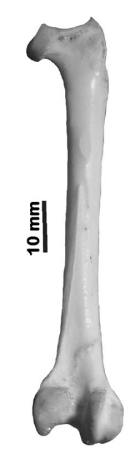

4

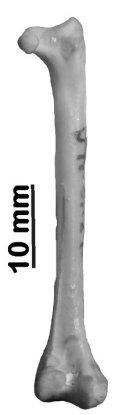

8

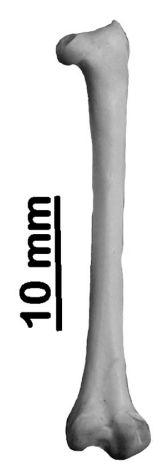

11

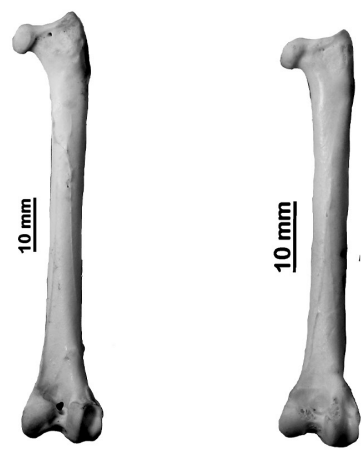

Plate 13.

Right femur (caudal aspect) - a. condylus lateralis; b. sulcus intercondylaris

1. Aegolius funereus; 2. Asio flammeus; 3. A. otus; 4. Athene noctua; 5. Bubo bubo; 6. Glaucidium passerinum; 7. Nyctea scandiaca; 8. Otus scops; 9. Strix aluco; 10. S. uralensis; 11 . Tyto alba

\section{3. táblakép}

Jobb oldali combcsont (palmáris nézet) - a. condylus lateralis; b. sulcus intercondylaris

1. Aegolius funereus; 2. Asio flammeus; 3. A. otus; 4. Athene noctua; 5. Bubo bubo; 6. Glaucidium passerinum; 7. Nyctea scandiaca; 8 . Otus scops; 9 . Strix aluco; 10. S. uralensis; 11 . Tyto alba 


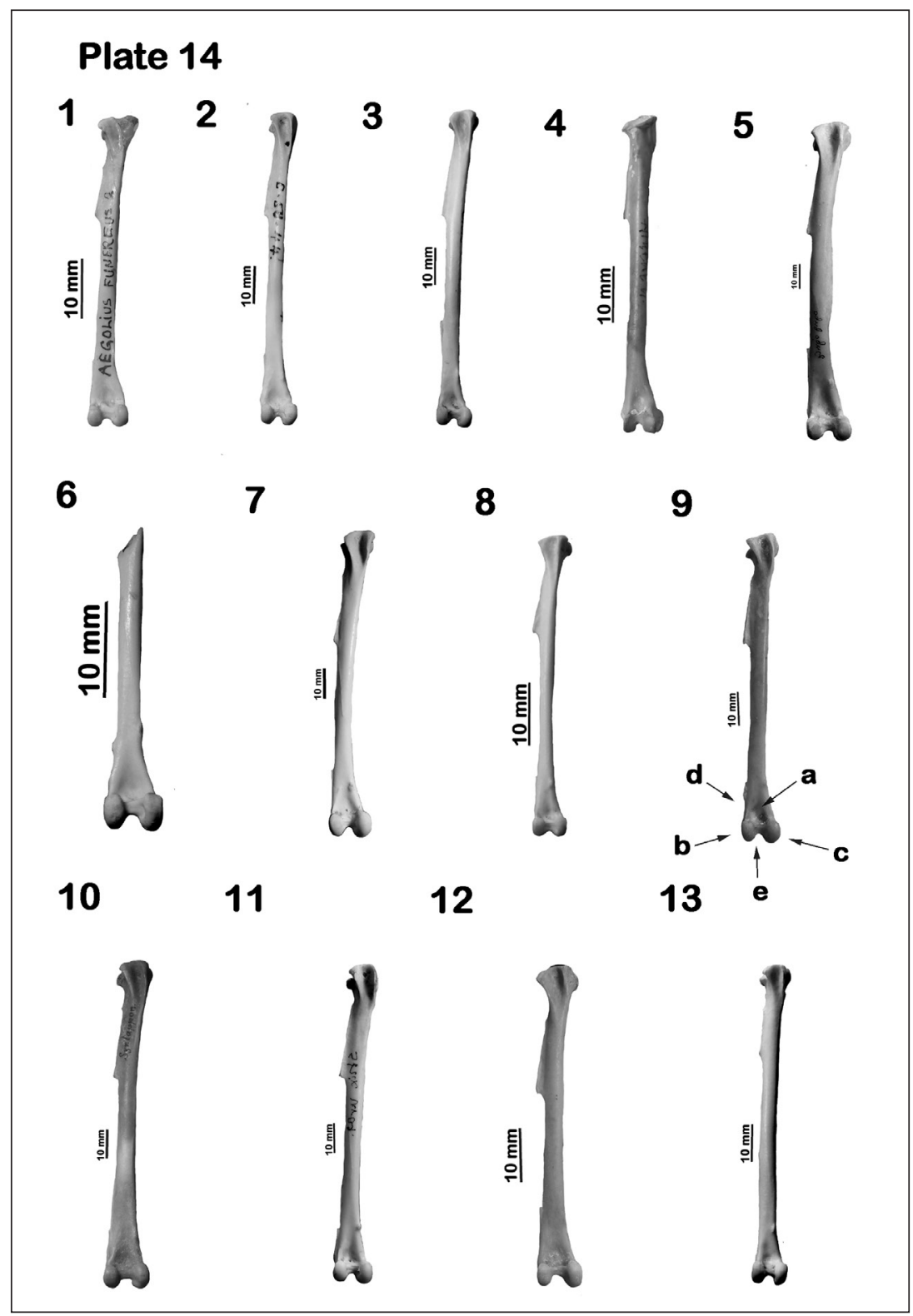

Plate 14.

Right tibiotarsus (cranial aspect) - a. sulcus extensorius; b. epicondylus lateralis; c. epicondylus medialis; d. tuberculum retinaculum musculi fibularis; e. incisura intercondylaris

1. Aegolius funereus; 2. Asio flammeus; 3. A. otus; 4. Athene noctua; 5. Bubo bubo; 6. Glaucidium passerinum; 7. Nyctea scandiaca; 8 . Otus scops; 9 . Strix aluco; 10. S. nebulosa; 11. S. uralensis; 12 . Surnia ulula; 13. Tyto alba

\section{4. táblakép}

Jobb oldali lábszárcsont (dorzális nézet) - a. sulcus extensorius; b. epicondylus lateralis; c. epicondylus medialis; d. tuberculum retinaculum musculi fibularis; e. incisura intercondylaris

1. Aegolius funereus; 2. Asio flammeus; 3. A. otus; 4. Athene noctua; 5. Bubo bubo; 6. Glaucidium passerinum; 7. Nyctea scandiaca; 8. Otus scops; 9 . Strix aluco; 10. S. nebulosa; 11. S. uralensis; 12 . Surnia ulula; 13. Tyto alba 


\section{Plate 15}

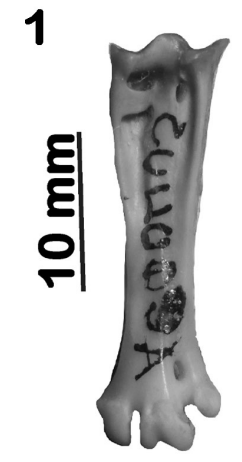

5
2

6

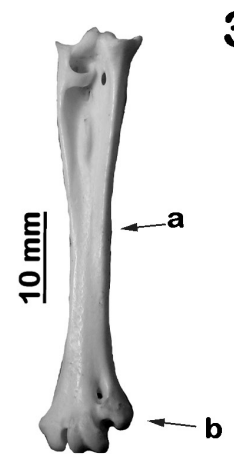

7

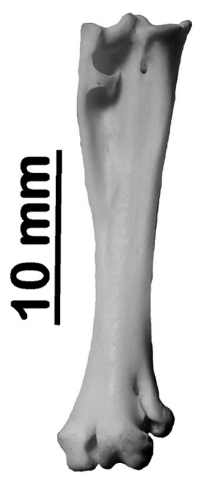

3
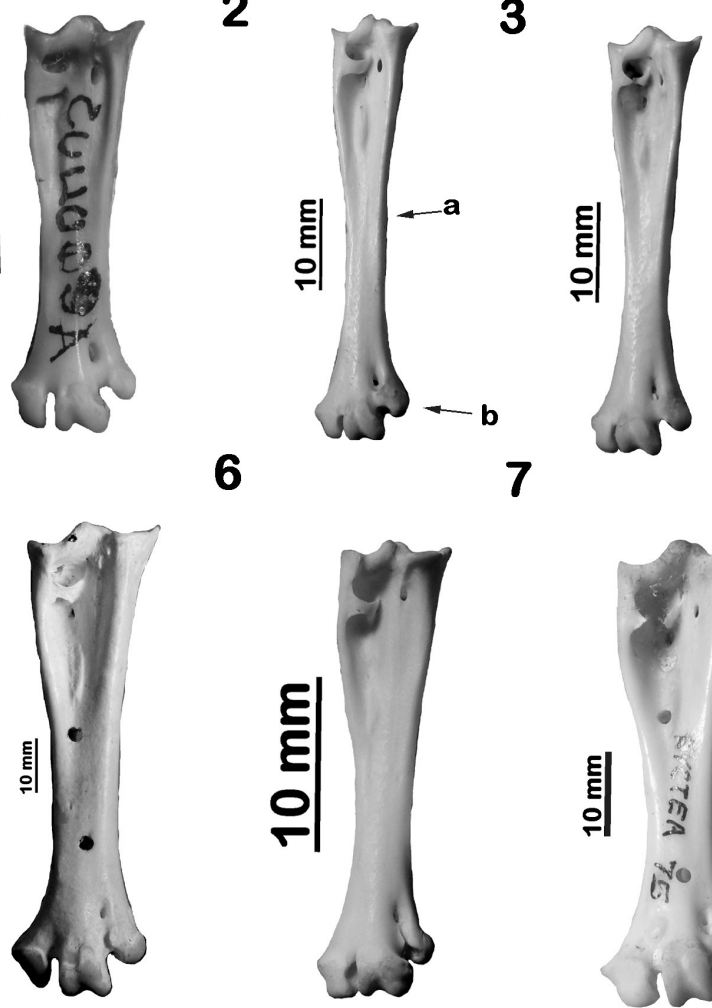

9
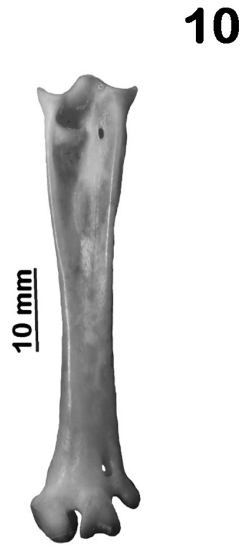

10

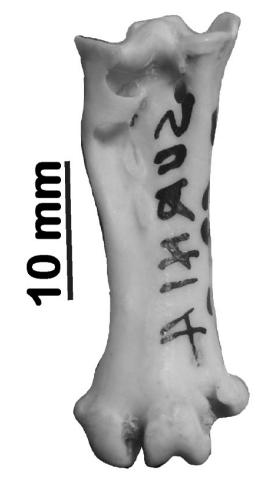

11

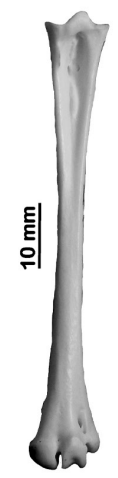

4

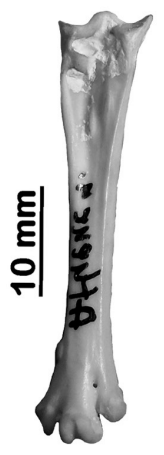

8
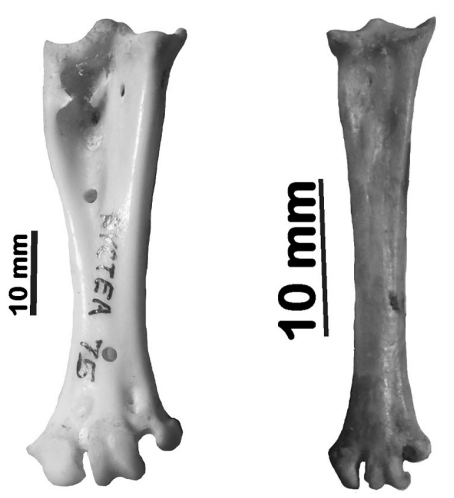

Plate 15.

Left tarsometatarsus (dorsal aspect) - a. diaphysis; $b$. trochlea metatarsi II.

1. Aegolius funereus; 2. Asio flammeus; 3. A. otus; 4. Athene noctua; 5. Bubo bubo; 6. Glaucidium passerinum; 7. Nyctea scandiaca; 8. Otus scops; 9. Strix aluco; 10 . Surnia ulula; 11 . Tyto alba

\section{5. táblakép}

Bal oldali csüd (háti nézet) - a. diaphysis; b. trochlea metatarsi Il.

1. Aegolius funereus; 2. Asio flammeus; 3. A. otus; 4. Athene noctua; 5. Bubo bubo; 6. Glaucidium passerinum; 7. Nyctea scandiaca; 8. Otus scops; 9. Strix aluco; 10. Surnia ulula; 11. Tyto alba 


\section{Plate 16.}
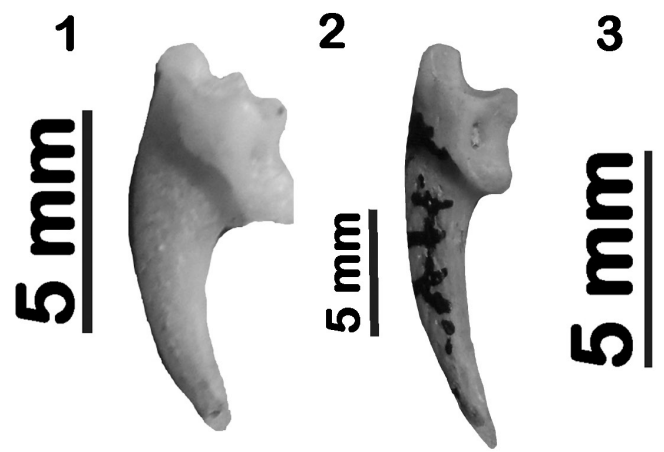

5

6
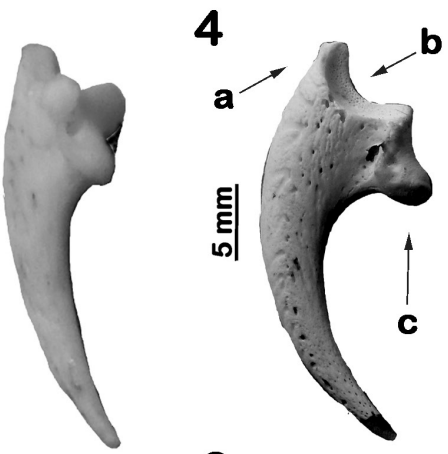

8
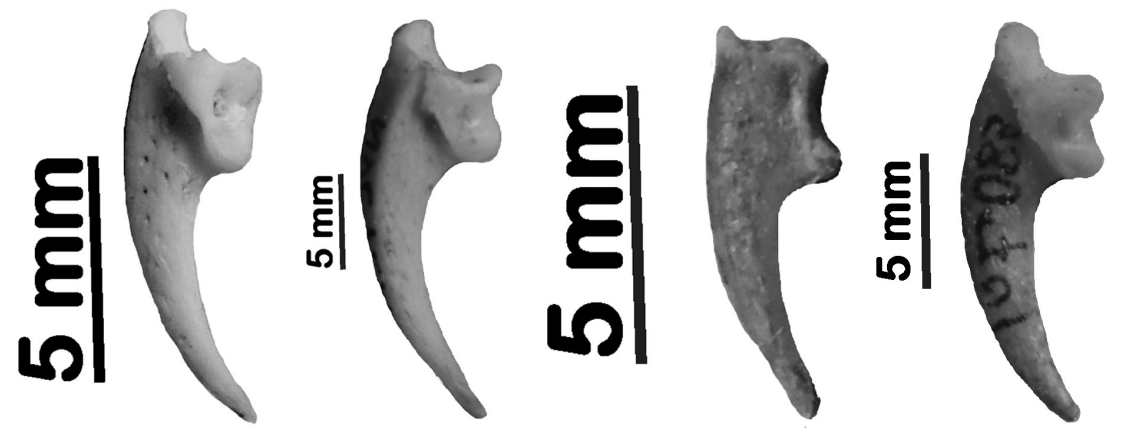

9

10

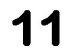

12
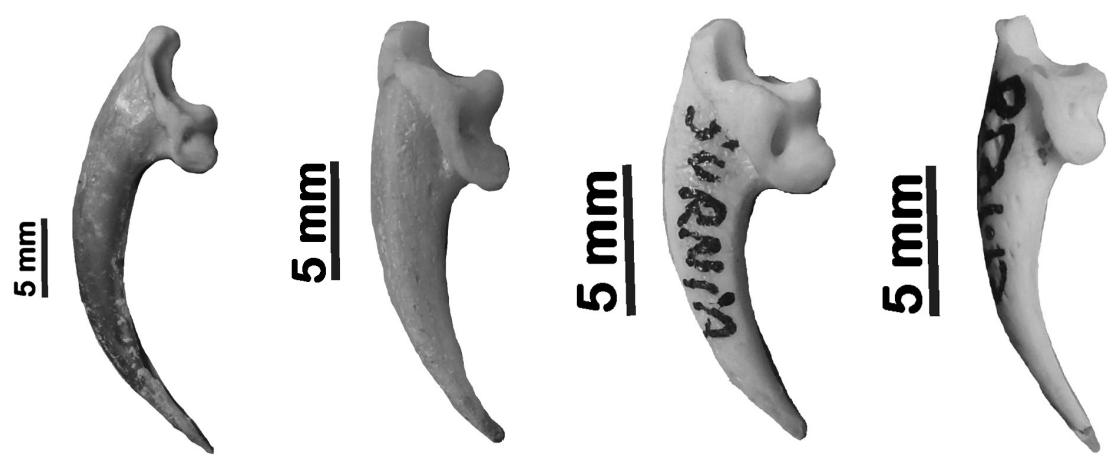

Plate 16.

Phalanx ungualis - a. tuberculum extensorium; b. cotyla articularis; c. tuberculum flexorium.

1. Aegolius funereus; 2. Asio flammeus; 3. Athene noctua; 4. Bubo bubo; 5 . Glaucidium passerinum; 6. Nyctea scandiaca; 7. Otus scops; 8. Strix aluco; 9 . Strix nebulosa; 10. Strix uralensis; 11 . Surnia ulula; 12. Tyto alba

16. táblakép

Karomcsont - a. tuberculum extensorium; b. cotyla articularis; c. tuberculum flexorium.

1. Aegolius funereus; 2. Asio flammeus; 3. Athene noctua; 4. Bubo bubo; 5. Glaucidium passerinum; 6. Nyctea scandiaca; 7. Otus scops; 8 . Strix aluco; 9. Strix nebulosa; 10. Strix uralensis; 11 . Surnia ulula; 12 . Tyto alba 


\section{References}

Ballmann, P. 1969. Die Vögel aus der altburdigalen Spaltenfüllung von Wintershof (West) bei Eichstätt in Bayern [The birds from the oldburdigalian column filling of Wintershof (West) near Eichstätt in Bavaria]. - Zitteliana 1: 5-61. (in German)

Ballmann, P. 1973. Fossile Vögel aus dem Neogen der Halbinsel Gargano (Italien) [Fossil birds from the neogene of the Gargano peninsula (Italy)]. - Scripta Geologica 17: 1-75. (in German)

Ballmann, P. 1976. Fossile Vögel aus dem Neogen der Halbinsel Gargano (Italien), zweiter Teil. - Scripta Geologica 38: 1-59. (in German)

Baumel, J. J., King, A. S., Lucas, A. M., Breazile, J. E. \& Evans, H. E. 1979. Nomina Anatomica Avium [Handbook of avian anatomy]. - Academic Press, London (in English and Latin)

Bindea, D. (ed.) 2008. Arheozoologia Transilvaniei in pre- si protoistorie [Transylvanian archaeozoology in Praeand Protoistory]. - Trognost Cluj-Napoca (in Romanian)

Bocheński, Z. 1997. List of European fossil bird species. - Acta Zoologica Cracoviensia 40(2): 293-333.

Bocheński, Z. M. \& Tomek, T. 1994. Fossil and subfossil bird remains from five Austrian caves. - Acta Zoologica Cracoviensia 37: 347-358.

Bökönyi, S. \& Jánossy, D. 1965. Szubfosszilis vadmadár leletek Magyarországon (Subfossile Wildvogelfunde aus Ungarn) [Subfossil wild bird remains from Hungary]. - Vertebrata Hungarica 7: 85-99. (in Hungarian and German)

Brodkorb, P. 1971. Catalogue of fossil Birds. Part IV. (Columbiformes through Piciformes). - Bulletin of the Florida State Museum, Biological Sciences 15(4): 163-266.

Čapek, V. 1917. A püspökfürdői preglaciális madárfauna [The Preglaciale bird fauna from Püspökfürdő]. - Barlangkutatás 5: 66-74. (in Hungarian)

Feduccia, A. 1999. The origin and evolution of birds. $2^{\text {nd }}$ edition. - New Haven, Yale University Press

Fischer, K. \& Stephan, B. 1977. Vogelknochenfunde aus Quartären Ablagerungen Südwestrumaniens [Bird bones from Quaternary deposits in Southwest Romania]. - Annalen für Ornithologie 1: 79- 90. (in German]

Gál, E. 1998. Avifauna fosilă a peșterii Gura Cheii de la Râșnov (Jud Brașov) [Fossil bird fauna of the Gura Cheii Cave from Râșnov (Brașov County)]. - Studia Universitatis Babeș-Bolyai, Biologia 43(1-2): 88-93. (in Romanian)

Gál, E. 2002. Avifauna pleistocena a Romaniei [Pleistocene bird faunas of Romania - (Unpublied C.Sc dissertation)]. - Universitatea din Bucureşti, Facultatea de Geologie București (in Romanian)

Gál, E. 2003. Bird remains from two Romanian caves: Curata Cave (Nandru) and Bordu Mare Cave (Ohaba Ponor). - ICAZ 2002. Abstracts: 56.

Gál, E. 2004. New evidence of fowling and poultry keeping in Pannonia, Dacia and Moesia during the period of the Roman Empire. - In: Gruppe, G. \& Peters, J. (eds.) Feathers, grit and symbolism. Birds and humans in the Ancient Old and New Worlds. - Proceedings of the $5^{\text {th }}$ Meeting of the ICAZ Bord Working Group, Munich, Germany, 26-30 July 2004. - Documenta Archaeobiologiae 3. Verlag Marie Leidorf GmbH. Rahden/ Westf., pp. 301-316.

Gál, E. 2005. Animal remains from archaeological excavations in North-Eastern Hungary. - In: Gál, E., Juhász, I. \& Sümegi, P. (eds.) Environmental archaeology in North-Eastern Hungary. - Varia Archaeologica Hungarica 19: 139-174.

Gál, E. 2007a The Neolitic avifauna of Hungary within the context of the Carpathian Basin. - Antaeus 27: 273-286.

Gál, E. 2007b Fowling in lowlands. Neolitic and Chalcholitic bird exploitation in South-East-Romania and the Great Hungarian Plain. - Archaeolinqua, Series Minor 24., Budapest

Gilbert, B. M., Martin, L. D. \& Savage, H. G. 1981. Avian Osteology. - 709 Kearney, Laramie, Wyoming

Hamar, M. \& Csák, K. 1969. Contribuţii la cunoaşterea faunei de vertebrate pleistocene din Dealul Burzău (com. Rîpa, jud. Bihor) - jung Würm. [Contributions to the knowledge pf pleistocene vertebrate fauna in Burzău Hill (Rîpa, Bihor county) - jung Würm] - Studii şi cercetări biologice, Seria Zoologie 21(6): 425. (in Romanian)

Harrison, C. J. O. \& Walker, C. A. 1975. The Bradycnemidae, a new family of owls from the Upper Cretaceous of Romania. - Palaeontology 18(3): 563-570.

Jarvis, E. D., Mirarab, S., Aberer, A. J., Li, B., Houde, P., Li, C. et al. 2014. Whole-genome analyses resolve early branches in the tree of life of modern birds. - Science 346(6215): 1320-1331. DOI: 10.1126/science.1253451 
Jánossy, D. 1952. Az Istállóskői barlang aurignaci faunája [The Aurignacian cave fauna from Istállóskő]. - Földtani Közlöny 82(4-6): 181-203. (in Hungarian)

Jánossy, D. 1954. Fossile Ornis aus der Höhle von Istállóskő [Fossile birds from the Istállóskő Cave]. - Aquila 55-58: 205-223. (in German)

Jánossy, D. 1955. Die Vogel-und Saugetierreste der Spätpleistozänen Schichten der Höhle von Istállóskő [The bird and mammalian remains of the Late Pleistocene Layers of the Istállóskő Cave]. - Acta Archaeologica Academiae Sciencentiarum Hungaricae 5: 149-181. (in German)

Jánossy, D. 1965. Fossiler Vogelfauna aus Mousterien Schichten der Curata-Hohle (Rumanien) [Fossil bird fauna from Mousterian layers of Curata Cave (Romania)]. - Vertebrata Hungarica 7(1-2): 106-16. (in German)

Jánossy, D. 1972. Die mittelpleistozäne Vogelfauna der Stránská Skála [The middle Pleistocene bird fauna of Stranská Skálá]. - Anthropos 21(12): 35-64. (in German)

Jánossy, D. 1973. The boundary of the Plio-Pleistocene based on the microvertebrates in north Hungary (Osztramos Locality 7). - Vertebrata Hungarica 14: 101-112.

Jánossy, D. 1974. Die mittelpleistozäne Vogelfauna von Hundsheim (Niederösterreich) [The Middle Pleistocene avifauna of Hundsheim (Lower Austria)]. - Sitzungsberichte der Österreichischen Akademie der Wissenschaften, Mathematisch-Naturwissenschftliche Klasse, Abteilung I. 182: 211-257. (in German)

Jánossy, D. 1977. Plio-pleistocene bird remains from the Carpathian Basin. III. Strigiformes, Falconiformes, Caprimulgiformes, Apodiformes. - Aquila 84: 9-36.

Jánossy, D. 1978. Új finomrétegtani szint Magyarország pleisztocén őslénytani sorozatában [A new fine stratigrafic level in Paleontological series at Hungarian Pleistocene]. - Földrajzi Közlemények 26(1-3): 161-174. (in Hungarian)

Jánossy, D. 1979. A magyarországi pleisztocén tagolása a gerinces faunák alapján [Layout of the Hungarian Pleistocene based on the Vertebrate fauna]. - Akadémiai Kiadó, Budapest (in Hungarian)

Jánossy, D. 1980. Plio-pleistocene bird remains from the Carpathian Basin. VI. Systematical and Geographical Catalogue. - Aquila 87: 9-22.

Jánossy, D. 1981. Die altpleistozänen Vogelfaunen von Deutsch-Altenburg 2 und 4 (Niederösterreich) [The Early Pleistocene bird fauna of Deutsch-Altenburg 2 and 4 (Lower Austria)]. - Beiträge zur Palaontologie von Österreich 8: 375-391. (in German)

Jánossy, D. 1982. Új adatok az európai madárfauna kialakulásáról [New data on the evolution of European bird fauna]. - Földtani Közlemények 112: 449-453. (in Hungarian)

Jánossy, D. 1983. Lemming-remain from the Older Pleistocene of Southern Hungary (Villany, Somssich Hill 2.). - Fragmenta Mineralogica et Paleontologica 11: 55-60.

Jánossy, D. 1985. Wildvogelreste aus archaeologischen Grabungen in Ungarn (Neoliticum bis Mittelalter) [Wild bird remains from archaeological excavations in Hungary (from the Neoliticum to the Middle Ages)]. - Fragmenta Mineralogica et Paleontologica 12: 67-103. (in German)

Jánossy, D. 1986. Pleistocene Vertebrate faunas of Hungary. - Akadémiai Kiadó, Budapest \& Elsevier, Amsterdam

Jánossy, D. 1990. Vertebrate fauna of site II. - In: Kretzoi, M. (ed.) Vértesszőlős: site, man and culture. - Akadémiai Kiadó, Budapest, pp. 187-229.

Jánossy, D. 1991. Late Miocene bird remains from Polgárdi (W-Hungary). - Aquila 98: 13-35.

Jánossy, D. 1992. Lower Pleistocene bird remains from Beremend (S-Hungary, Loc. 15. and 16.). - Aquila 99: 9-25.

Jánossy, D. 1993. Bird remains from the Upper Miocene (MN 9) of Rudabánya (N-Hungary). - Aquila 100: 53-70.

Jánossy, D. 1995. A Late Miocene avifauna from Polgárdi, Western Hungary. - Acta Palaeornithologica, Courier Forschungsinstitut Senckenberg 181: 203-206.

Jánossy, D. \& Kordos, L. 1976. Az Osztramos gerinces lelőhelyeinek faunisztikai és karszt-morfológiai áttekintése (1974-ig) [The faunistic and karst-morphological overview of the sites from Osztramos (until 1974)]. Fragmenta Mineralogica et Paleontologica 8: 39-92. (in Hungarian)

Jurcsák, T. \& Kessler, E. 1986. Evoluţia avifaunei pe teritoriul României (I) [Evolution of the avifauna in the territory of Romania, Part I.]. - Crisia 16: 577-615. (in Romanian with English Summary)

Jurcsák, T. \& Kessler, E. 1988. Evoluţia avifaunei pe teritoriul României (III) [Evolution the avifauna on the territory of Romania, Part III.]. - Crisia 18: 647-688. (in Romanian with English Summary)

Kessler, E. 1974a Avifauna postglaciară de la Cuina Turcului, Cazanele Mari, România [Postglacial avifauna from Cuina Turcului, Cazanele Mari, Romania]. - Tibiscus 11: 113-122. (in Romanian) 
Kessler, E. 1974b Date noi asupra avifaunei fosile a Dealului Burzău - Râpa [New data to fossil bird fauna from Burzau Hill (Village Rîpa)]. - Nymphaea 2: 159-167. (in Romanian)

Kessler, E. 1975. Contribuţii noi la studiul avifaunei fosile de la Betfia, jud. Bihor [New contributions to fossile avifauna from Betfia, Bihor County]. - Nymphaea 3: 53-59. (in Romanian)

Kessler, E. 1982. Avifauna fosilă şi subfosilă a Munţilor Apuseni [Fossil and subfossil bird fauna from Apuseni Mountains]. - Nymphaea 10: 171- 181. (in Romanian)

Kessler, E. 1985. Contribuţii noi la studiul avifaunelor cuaternare din România [New contributions to the study of Quaternary bird faunas in Romania]. - Crişia 15: 485-491. (in Romanian)

Kessler, E. \& Gál, E. 1997. Resturi fosile şi subfosile de păsări din Banat [Fossil and subfossil bird remains in Banat]. - Analele Banatului - Ştiinţele Naturii 3: 141-144. (in Romanian with English Summary)

Kessler, J. 2010. Új eredmények a Kárpát-medence neogén és negyedidőszaki madár-világához III. [New results with regard to the neogene and Quaternary avifauna of the Carpathian Basin, Part III.]. - Földtani Közlöny 140(1): 53-72. (in Hungarian with English Summary)

Kessler, J. 2013. A Kárpát-medence madárvilágának őslénytani kézikönyve [Paleontological handbook of birdlife in the Carpathian Basin]. - Könyvműhely, Miskolc (in Hungarian)

Kessler, J. \& Hír, J. 2012. Észak-Magyarország madárvilága a miocénben II. [The avifauna in North Hungary during the Miocene, Part II.]. - Földtani Közlöny 141(2): 149-168. (in Hungarian with English Summary)

Kordos, L. 1984. A bodajki Rigó-lyuk újholocén kitöltésének vizsgálata [Examination of Bodajk Rigó-hole filling in Holocene]. - Folia Musei Historico-Naturalis Bakonyensis 3: 31-42. (in Hungarian)

Kormos, T. 1913. Kleinere Mitteilungen aus dem ungarischen Pleistozän [Small releases from the Hungarian Pleistocene]. - Centralblatt für Mineralogie, Geologie und Palaontologie 1913: 13-17. (in German)

Kretzoi, M. 1957. Madármaradványok a Csákvári faunából [Fossil bird remains from Csákvár Fauna]. - Aquila 63-64: 239-248. (in Hungarian)

Kretzoi, M. 1961-62. Madár-maradványok a betfiai alsópleisztocén faunából [Bird remains in the Lower Pleistocene fauna from Betfia]. - Aquila 67-68: 167-174. (in Hungarian)

Lambrecht, K. 1912. A borsodi Bükk fossilis madarai (Fossile Vögel des Borsoder Bükkgebirges) [Fossil birds of the Bükk Mountains from Borsod]. - Aquila 19: 270-287. (in Hungarian and German)

Lambrecht, K. 1913. Neueren Daten zur fossilen Ornis unseren Höhlen [Recent data for fossil birds in our caves]. - Barlangkutatás 1: 173. (in German)

Lambrecht, K. 1915. Fossilis nagy fülesbagoly (Bubo maximus Flemm.) és egyéb madármaradványok a magyarországi pleistocénből [Fossil's Big-eared Owl (Bubo maximus Flemm.) and other bird remains in Hungarian Pleistocene]. - Aquila 22: 177-187. (in Hungarian)

Lambrecht, K. 1916. Az első magyar preglaciális madárfauna - Die erste ungarische praglaziale Vogelfauna [The first Hungarian Preglaciale bird fauna]. - Aquila 22: 165-172. (in Hungarian and German)

Lambrecht, K. 1933. Handbuch der Palaeornithologie [Handbook of Palaeornithology]. - Gebrüder Borntraeger, Berlin (in German)

Langer, G. 1980. Vergleiche morphologische untersuchungen an Einzelknochen in Mitteleuropa Vorkommender mittelgrosser Eulenarten [Comparative morphological investigations of single bones occurring medium-sized owl species in Central Europe]. - Inaugural dissertation for obtaining the veterinary doctor's degree of the Veterinary Faculty of the Ludwig-Maximilians-University of Munich (in German)

Malez, M. 1961. Pecinska hijena iz indije kod Voce [The Cave Hyaenas come from Vindija Cave]. - Geologiceskij Vjesnik 14: 221-244. (in Croatian)

Malez, M. \& Rukavina, D. 1975. Kristurbacijske pojave u gornjopleistocenskim nasla-gama pecine Vindije kod Donje Voce u sjeverozapadnoj Hrvatskoj [Cristurbation appearance in Upper Pleistocene at Vindija Cave in Northwest Croatia]. - Rad Hazu knj. 371: 245-265. (in Croatian)

Malez, V. 1973. Fosilne ptice Jugoslavije [Fossil birds from Yugoslavia]. - Unpublished Dissertation, Zagreb University (in Croatian)

Malez, V. 1984. Paleornitološki ostaci iz kvartarnih naslaga nekih spilja Hrvatske i Slovenije [Paleornithological remains from the Quaternary Sediments of some Croatian and Slovenian caves]. - Deveti jugoslavenski speleoloski kongres, Zbornik predavanja, pp. 711-719. (in Croatian)

Malez, V. 1988. Pleistocenska ornitofauna iz spilje Vindije u sjevernozapadnoj Hrvatskoj [Pleistocene bird fauna from Vindija Cave in Northwestern Croatia]. - Rad Jugoslavenske Akademije Znanosti i Umjetnosti, Varazdin 2: 31-203. (in Croatian) 
Milne-Edwards, A. 1863. Mémoire sur la distribution géologique des oiseaux fossiles et description de quelques espèces nouvelles. [Memory on the geological distribution of fossil birds and description of some new species]. - Annales des Sciences Naturelles (4) 20: 132-176. (in French)

Milne-Edwards, A. 1892. Sur les oiseaux fossiles des dépots éocènes de phosphate de chaux du Sud de la France [Fossil birds on Eocene deposits of lime phosphate South of France]. - In: Sclater, P. L. (ed.) Comptes Rendus du Second Congrès Ornithologique International [Reports of the Second International Ornithological Congress]: pp. 60-80. Budapest (in French)

Mlíkovskỳ, J. 1998a A new Barn Owl (Aves: Strigidae) from the early Miocene of Germany, with comments on the fossil history of the Tytoninae. - Journal für Ornithologie 139: 247-261.

Mlíkovskỳ, J. 1998b Two new owls (Aves: Strigidae) from the early Miocene of the Czech Republic, with comments on the fossil history of the subfamily Striginae. - Buteo 10: 5-21.

Mlíkovskỳ, J. 2002. Cenozoic birds of the World. Part I.: Europe. - Ninox Press, Praha, 407.

Mottl, M. 1941. Die Interglazial- und Interglazialzeiten im Lichte der Ungarischen Saugetierfauna [Interglacial and interglacial times in the light of Hungarian mammalian fauna]. - Mitteilungen aus dem Jahrbuche der Königlich Ungarischen Geologischen Anstalt 35: 13-39. (in German)

Mottl, M. 1953. Die Erfrorschung der Höhlen [The exploration of the caves]. - Jahrb. Naturwiessenschaft Abteilung Johanneum, Graz, pp. 19-58. (in German)

Mourer-Chauviré, C. 1987. Les Strigiformes (Aves) des Phosphorites du Quercy (France): Systématique, biostratigraphie et paléobiogéographie [Strigiformes (Aves) from the Phosphorites of Quercy (France): Systematics, biostratigraphy and paleobiogeography]. - In: Mourer-Chauviré, C. (ed.) L'évolution des oiseaux d'après le témoignage des fossiles [The evolution of birds according to the testimony of fossils]. - Documents des Laboratoires de Géologie de Lyon 99: 89-135. (in French)

Nehring, A. 1880. Uebersicht über vierundzwanzig mitteleuropäische Quartär-Faunen [Survey of twenty-four Central European Quaternary fauna]. - Zeitschrift der Deutschen Geologischen Gesellschaft 32: 468-509. (in German)

Olson, S. L. 1985. The fossil record of birds. - Avian Biology 7: 80-252.

Pike-Tay, A., Bartosiewicz, L., Gál, E. \& Whitle, A. 2004. Body part representation and seasonility: sheep/goat, bird and fish remains from Early Neolitic Ecsegfalva 23 SE Hungary. - Journal of Taphonomy 2(4): 221-246.

Róth, S. 1881. Szepesmegye néhány barlangjának leirása [Description of some caves in Szepes County]. - Mathematikai és Természettudományi Közlemények 16: 613-648. (in Hungarian)

Soergel, E. 1966. Die Vogelreste [The Bird Remains]. - In: Ehrenberg, K. (ed.) Die Teufels-oder Fuck-senlucke bei Eggenburg (NÖ) [The Devil or Fuck senlucke at Eggenburg (NA)]. - Denkschriften der Mathematisch-Naturwissenschftliche Klasse der Österreichischen Akademie der Wissenschaften, pp. 93-107. (in German)

Tyrberg, T. 1998. Pleistocene birds of the Palearctic: a catalogue. - Publications of the Nuttall Ornithological Club, No. 27., Cambridge

von den Driesch, A. 1976. A guide to the measurements of animal bones from archaeological sites. - Peabody Museum Bulletin 1.

Wettstein, O. V. \& Mühlhofer, F. 1938. Die Fauna der Höhle von Merkenstein in N-Ö [The fauna of the Merkenstein Cave in North Austria]. - Archiv Naturgeschichte, new series 7(4): 514-558. (in German)

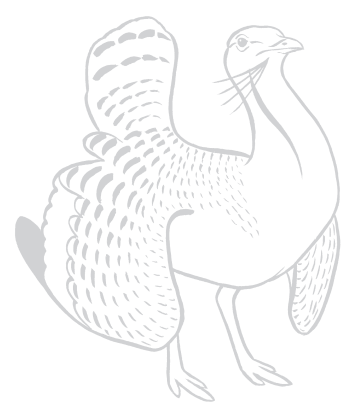

